CESIS Electronic Working Paper Series

Paper No. 460

\title{
The Impact of FDI on Regional Air Pollution in the Republic of Korea: A Way Ahead to Achieve the Green Growth Strategy?
}

\author{
Erik Hille \\ Muhammad Shahbaz \\ Imad Moosa
}

May, 2018 
The Impact of FDI on Regional Air Pollution in the Republic of Korea: A Way Ahead to Achieve the Green Growth Strategy?

\author{
Erik Hille \\ HHL Leipzig Graduate School of Management, Germany \\ Email: Erik.Hille@hhl.de \\ Muhammad Shahbaz \\ Montpellier Business School, France \\ Email: muhdshahbaz77@gmail.com \\ Imad Moosa \\ RMIT University, Australia \\ Email: Imad.Moosa@rmit.edu.au
}

Version May 7, 2018

\begin{abstract}
Can FDI help to reduce regional air pollution emissions in Korea? Given the proclamation of a far-reaching national green growth strategy that requires a shift in public and private investments, this paper addresses the need for empirical estimates on the environmental consequences of FDI inflows into Korea. Using a simultaneous equations model the impacts of FDI inflows are decomposed into direct as well as indirect scale, composition, and technique effects. Thereby, the analysis utilizes panel data on six air pollutants in 16 Korean provinces and self-governing cities for the time period 2000 to 2011. The estimation results show that FDI inflows concurrently stimulate regional economic growth and reduce air pollution intensities. However, the total level of air emissions mostly remains unchanged. While confirming the findings of the existing national level research on the FDI-growth relationship in Korea, the results are partly contrary to the respective earlier findings on the FDI-environment nexus. Given Korea's high level of development paired with the aforementioned impact on economic growth and air pollution intensities, foreign investments are, therefore, regarded as one potential pillar to achieve the goals of the green growth strategy.
\end{abstract}

Keywords: Foreign Direct Investments, Air Pollution, Green Growth, Decomposition Analysis, Republic of Korea

JEL Classification: F21, O44, Q53, Q56 


\section{Introduction}

Following the proclamation of Lee Myung-bak, President of the Republic of Korea, in 2008 Korea has embarked on a far-reaching green growth strategy. This marked a significant change in the country's official political agenda as until then Korea was not necessarily known as a forerunner in environmental protection. ${ }^{1}$ The first Five-Year Plan for Green Growth (2009-2013) and the National Strategy (2009-2050) set the respective short and long term policy framework specifying that in particular a shift in both public and private investments is required. In this context, FDI is seen as one of the engines to stimulate economic growth and the adoption of environmentally friendly technologies (Jones and Yoo 2011). ${ }^{2}$ In the wake of the Asian financial crisis Korea has already subsequently relaxed its restrictive FDI policies and attempted to attract FDI inflows. Based on the OECD FDI Regulatory Restrictiveness Index ${ }^{3}$ between 1997 and 2010 the country experienced the strongest increase in FDI liberalization in a sample of 40 developed and newly industrialized countries (Nicolas et al. 2013). While several articles estimate the effect of FDI inflows on economic growth and reveal some positive evidence for Korea (Carkovic and Levine 2005, Kim and Seo 2003, Koojaroenprasit 2012), the environmental consequences of FDI inflows to Korea have not been analyzed thoroughly. Yet, an analysis of the latter relationship is of utmost importance to evaluate the role that FDI may inherit with regards to the country's green growth strategy.

In order to analyze the FDI-environment nexus the approach of Antweiler et al. (2001) has often been applied. They developed a theoretical model to decompose the impact of trade opening on the environment into a scale, composition, and technique effect. Concerning the impact of FDI, the scale effect refers to the magnitude that pollution grows because of an increase in economic activity. The effect that FDI may alter the industrial structure is called the composition effect. Depending on which sector gains relative importance regarding the total economy's production, the structural change may either positively or negatively affect pollution. The technique effect denotes the extent to which FDI fosters the implementation of technological innovations to reduce the pollution intensity of output.

This paper will test whether FDI is good or bad for the Korean environment to draw conclusions on the extent that FDI may contribute to the long term green growth path. Thereby, the focus lies on province-level air pollution. To ensure robustness of the results the impact on six air pollutants is analyzed. ${ }^{4}$ As Korea's economy leverages an advanced

\footnotetext{
${ }^{1}$ Even though large parts of the environmental legislation were reformed throughout the 1990s, firms in Korea only slowly adopted cleaner technologies. Therefore, energy, carbon, and several material intensities remained among the highest in the OECD (Chung 2014). Also several policy indicators suggest that Korea had a medium to low regulatory stringency compared to other rather advanced economies. For instance, during the time period 1995 to 2008 Korea ranked 13th and 18th out of 28 OECD countries regarding the average environmental policy stringency index of the OECD (2017) and the average climate policy stringency index of Althammer and Hille (2016) respectively.

2 In general, research has analyzed two conflicting hypotheses on the effects of FDI and trade on the environment (Albornoz et al. 2009; Chung 2014; Hille 2018; Zarsky 1999). First, as in the case of Korea's green growth strategy it is argued that foreign enterprises may bring their environmental knowledge and advanced technologies. This may entail a so-called 'pollution halo' through spillovers to domestic firms and result in a clean-up of the environment. Second, foreign firms may seek to gain a competitive advantage by relocating their dirty production to countries with lower environmental standards, which as a result may become 'pollution havens'.

${ }^{3}$ The OECD FDI Regulatory Restrictiveness Index measures statutory restrictions on FDI by looking at foreign equity limitations, screening or approval mechanisms, restrictions on the employment of foreigners as key personnel, and operational restrictions (OECD 2017).

4 The six air pollutants are carbon monoxide $(\mathrm{CO})$, sulfur oxides $\left(\mathrm{SO}_{\mathrm{x}}\right)$, mono-nitrogen oxides $\left(\mathrm{NO}_{\mathrm{x}}\right)$, total suspended particles (TSP), particulate matter $\left(\mathrm{PM}_{10}\right)$, and volatile organic compounds (VOC).
} 
technological infrastructure where influences may tend to come into effect through a network of interactions, a system of simultaneous equations is estimated. This allows not only to determine the drivers of the individual scale, composition, and technique effect but also to control for potential endogeneity. Moreover, in order to improve the accuracy of the estimates of the three effects, the simultaneous equations estimation includes both the direct as well as indirect impacts of FDI on the pollution emissions and a feedback effect of the pollution emissions on FDI. For the analysis panel data on 16 Korean provinces and self-governing cities from 2000 to 2011 are utilized. ${ }^{5}$ Among other things, the regression results show that FDI inflows simultaneously stimulate regional economic growth and significantly reduce air pollution intensities. This is at least partly contrary to the earlier findings of Aden et al. (1999), who analyze two Korean manufacturing sectors and detect during a time period when total air emissions rose that domestic firms spent more on pollution abatement than firms with some level of foreign ownership. Especially the negative indirect technique effect, which can be mainly attributed to the positive impact of FDI on per capita income and the demand for environmental quality, contributes to the reduction in air pollution intensities. However, as the relatively strong technique effect is leveled out by the joint impact of the scale and composition effect, the total level of air emissions mostly remains unchanged. The paper also reveals that the impacts of FDI on air emissions vary significantly among regions. Hence, the results suggest that foreign enterprises may contribute to the success of the Korean green growth strategy by supporting growth and the clean-up of industrial production. Yet, environmental and economic policies need to accommodate for regional differences.

The paper continues as follows: In the next section the empirical literature on the environmental impact of FDI is detailed. The development of air pollution, the green growth strategy, and FDI in the Republic of Korea is subsequently illustrated in Section-III. In section-IV and V the used methodology and data for the estimation of the system of structural equations are introduced respectively. The results of the simultaneous equations estimation are presented and discussed in Section-VI, followed by the conclusion in Section-VII.

\section{Empirical Literature}

Among others, Cole et al. (2017) and Shahbaz et al. (2015) provide an overview of the empirical literature. A large variety of methods are used to analyze the FDI-environment relationship. These include but are not limited to: input-output models (Jiang et al. 2015), causality tests (Omri et al. 2014), computable general equilibrium models (Hübler 2011), and variance decomposition analyses (Yang et al. 2008). Another research stream considers the environmental impact of FDI in the context of the Environmental Kuznets Curve, which describes the relationship between economic development and environmental degradation (Lau et al. 2014, Neequaye and Oladi 2015). This practice of using a simple curve to describe the growth-pollution nexus is questioned by Copeland and Taylor (2004), who argue that depending on the main driver of growth its environmental impact may vary considerably. Using the same reasoning FDI is likely not to influence pollution as an isolated factor but rather through several interlinked channels. Therefore, studies have decomposed the environmental effects of FDI into three major channels, namely economic scale, industrial composition, and a technique effect (Bao et al. 2011, Yang et al. 2013).

While the majority of research using this approach is on China, only few articles on other countries exist. Early work has been carried out by Liang (2006) and He (2006), who analyze

\footnotetext{
5 The analyzed time-period is limited by the availability of regional FDI data, which is not publicly available. Until 2012 the Republic of Korea had 16 provincial level divisions, namely eight provinces, the special autonomous province Jeju, six metropolitan cities, and the special city Seoul. In 2012 the special autonomous city Sejong opened.
} 
sulfur dioxide $\left(\mathrm{SO}_{2}\right)$ emissions for 260 cities and 29 provinces in China respectively. The former bases its analysis on a reduced form equation and finds a negative correlation between FDI and air pollution for the time period 1996 to 2003. In other words, FDI may be beneficial for the environment. Despite a similar general finding that foreign enterprises produce with higher pollution efficiency, He (2006) reveals that FDI had a very small deteriorating effect on industrial $\mathrm{SO}_{2}$ emissions between 1994 and 2001. Thereby, she employs a system of simultaneous equations to estimate the FDI-emission relationship. In subsequent articles this methodology has often been applied in multiple ways, because it allows jointly modeling the three effects as well as the complex interactions between the partly endogenous variables.

For instance, He (2008), Bao et al. (2011), and Yang et al. (2013) also utilize simultaneous equations estimations. In He (2008), the FDI-environment relationship is analyzed for 80 Chinese cities between 1993 and 2001 for two air pollution variables, namely the $\mathrm{SO}_{2}$ concentration and total suspended particles (TSP). Overall, a very small deteriorating effect of FDI is exposed. Contrary to that Bao et al. (2011) reveal that the environmental impact of FDI is heterogeneous depending on pollutant and region. They analyze the emissions of five pollutants, including air and water pollution as well as solid waste, for 29 Chinese provinces for the time frame 1992 to 2004. By capturing both a direct and an indirect technique effect, Bao et al. (2011) further detail the environmental impact of FDI. Their results show that for four out of five pollutants investments of foreign firms help to reduce emissions. The largest beneficial effects are estimated for the air emissions, i.e. industrial $\mathrm{SO}_{2}$ and industrial smoke. Similar results are found by Yang et al. (2013), who compare the environmental effects of domestic and foreign capital for six different pollution intensities in 25 Chinese provinces between 1992 and 2008. Even though no significant differences for wastewater and gas emissions are revealed, foreign capital has a significantly lower effect on emissions than domestic capital for the remaining four industrial pollutants, namely $\mathrm{SO}_{2}$, dust, solid waste, and chemical oxygen demand (COD). Thus, from an environmental perspective Yang et al. (2013) recommend not to discriminate but rather to encourage FDI inflows.

For a set of different countries the impact of FDI on the environment is e.g. estimated by Antweiler et al. (2001) as well as more recently by Kheder (2010) and Pazienza (2015), who both employ sector-level data. While decomposing the environmental effect of trade openness, Antweiler et al. (2001) add the ratio of the inward FDI stock to the overall capital stock as an additional explanatory variable. For the years 1971 to 1996 they reveal that an increase in the FDI intensity results in either no or only very small increases in the $\mathrm{SO}_{2}$ concentrations. Also Kheder (2010) finds mixed effects for French FDI outflows to developed, developing, and emerging economies between 1999 and 2003. While the French foreign investments in the manufacturing sector are found to have detrimental effects on carbon dioxide $\left(\mathrm{CO}_{2}\right)$ emissions, the opposite relationship is revealed with regards to local water pollution. Using a reduced-form equation Pazienza (2015) focuses on the impact of FDI inflows into the transport sector on $\mathrm{CO}_{2}$ emissions from fuel combustion. For a set of 30 OECD countries FDI entailed a rather small reduction in emissions during the time period 1981 to 2005.

Overall, research has found heterogeneous results when the scale, composition, and technique effect of FDI are simultaneously considered. Yet, FDI mainly inherits either a beneficial role or has only a rather small negative impact on the environment. At the same time, pollution associated with foreign capital is often shown to be lower than with domestically financed capital. 
To the authors' knowledge there does not exist empirical research that decomposes the environmental impact of FDI inflows into Korea into the three major effects. Also in general only few articles on Korea can be found with regards to the trade-environment nexus and specifically on the influence of FDI. Aden et al. (1999) analyze survey data on manufacturing plants in the textile and petrochemicals sector and detect that firms with some level of foreign ownership spent less on pollution abatement than domestic firms. They partly interpret this as an anticipatory action of the Korean conglomerates, which dominate industrial production, in order to protect themselves from public criticism. More recently, Choi et al. (2011) investigate the relationship between $\mathrm{CO}_{2}$ emissions and trade openness, which is measured as the sum of imports and exports as the share of gross domestic product. By carrying out an analysis on the national level the authors find that the nexus can be represented by an inverted U-shaped curve. Thus, after leading to an initial increase in the carbon intensity, higher trade flows are associated with a reduction in the carbon intensity.

\section{Air Pollution, Green Growth, and FDI in Korea}

The development of six air pollution emissions with strong local effects is shown in Figure-1. Specifically, this paper analyzes carbon monoxide $(\mathrm{CO})$, mono-nitrogen oxides $\left(\mathrm{NO}_{\mathrm{x}}\right)$, sulfur oxides $\left(\mathrm{SO}_{\mathrm{x}}\right)$, total suspended particles (TSP), particulate matter $\left(\mathrm{PM}_{10}\right)$, and volatile organic compounds (VOC). On the national level during the analyzed time period from 2000 to 2011 the total emissions of three out of six air pollutants rose, namely of TSP, PM 10 , and VOC. In particular the emission level of TSP and $\mathrm{PM}_{10}$ increased drastically by 146 and 113 percent respectively. The remaining levels of air emissions decreased between 7 and 20 percent. Apart from $\mathrm{NO}_{\mathrm{X}}$ and VOC, which experienced emissions increases of 9 and 4 percent between 2011 and 2014, the emission levels of the remaining pollutants decreased between 17 and 27 percent after the year 2011. The situation also evolved a bit more positive with regards to the air pollution intensities, i.e. the total emissions per gross domestic product. Specifically, the pollution intensity of four pollutants decreased between 2000 and 2011. $\mathrm{CO}, \mathrm{SO}_{\mathrm{x}}$, and $\mathrm{NO}_{\mathrm{x}}$ experienced the largest reductions with 50,45 , and 42 percent. Only the pollution intensity of TSP and $\mathrm{PM}_{10}$ increased by 54 and 33 percent. Major sources of this increase are the transportation sector relying on fossil fuels, the energy sector using predominantly oil- and coal-fired thermal power plants, and various industrial production activities (NIER 2018). While the pollution intensities of $\mathrm{NO}_{\mathrm{X}}$ and VOC remained almost constant from 2011 onwards, the pollution intensities of the other emissions decreased considerably between 23 to 32 percent from 2011 to 2014.

Figure-1: Development of Total Air Pollution Emissions in Korea ${ }^{a, b}$

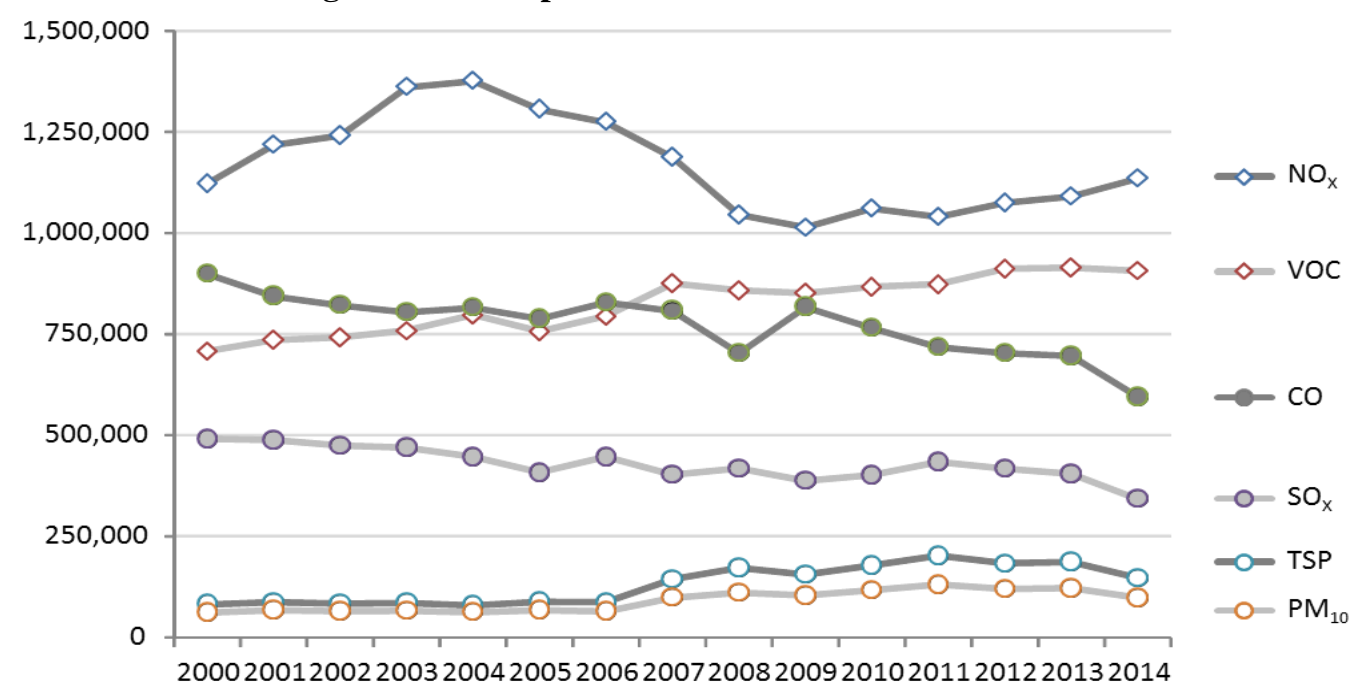

Note: ${ }^{\mathrm{a}}$ In tons; ${ }^{\mathrm{b}}$ Self-prepared using NIER (2018) 
Despite the partial decreases of emissions intensities, for a number of pollutants the air quality is still below the level of other advanced economies. ${ }^{6}$ This holds especially for the Seoul metropolitan region (OECD 2010). Mainly small and medium-sized Korean firms have not yet adopted clean technologies even though the environmental regulation was completely reformed throughout the 1990s. Consequently, not only the air pollution with local effects is above average, but also carbon, energy, and several material intensities are among the highest of the OECD countries (Chung 2014). Partly in response to the comparatively high level of emissions, the Korean government committed itself to a green growth strategy in 2008. This represented a drastic change in policy in particular given Korea's past reluctance to decrease greenhouse gas emissions on the basis of international agreements such as the Kyoto Protocol. Yet, the high dependence on fossil fuels and resource imports paired with an industry structure focusing mainly on energy-intensive sectors were demanding a change of the historic brown growth paradigm (Kim and Thurbon 2015). Thus, the green growth strategy is besides its environmental benefits designed as an industrial strategy. It aims to ensure the future development by creating a new export platform through the promotion of technological innovations and key industries (Mathews 2012). This is also reflected in the ten policy directions of the long term National Strategy (2009-2050) focusing mainly on three goals, i.e. the reduction of local and global air pollutants and the enhancement of energy security, the transformation of the industrial structure and technological base to promote green growth, and international leadership in improving the quality of life. In order to achieve the objectives, among other things, significant infrastructure investments, public research and development, and an adaption of regulatory and market correction measures are planned (Mathews 2012). Overall, even though Korea is a late starter, the green growth strategy is compared to other countries regarded as highly ambitious in terms of targets and investment scale, wellstructured and executed, and quickly deployed (Kim and Thurbon 2015).

One potential pillar to accomplish the long term goals of the green growth strategy may be foreign investments. FDI in green growth industries has been prioritized since the foreign investment promotion plan from February 2011 (Mun and Mun 2015). Already beforehand Korea relaxed its restrictive FDI policies and tried to attract FDI inflows. While in the 1980s nearly 600 sectors were completely closed to FDI, this number had been reduced to three sectors by the mid-1990s. Yet, the complete liberalization occurred with a lag and was accelerated by the Asian financial crisis in 1997, which is reflected in the strong improvement of the OECD FDI Regulatory Restrictiveness Index (Nicolas et al. 2013). This resulted in a sharp increase of FDI inflows reaching their maximum in the years 1999 and 2000. The temporary peak can be mainly attributed to foreign minority owners of joint ventures acquiring their partly distressed Korean partners. From 2000 onwards FDI mainly has taken the form of greenfield investments resulting in a reduction of FDI inflows (Noland 2007). Only in 2014 the level of FDI inflows of the year 2000 was again reached. This development along with the regional distribution of FDI is depicted in Figure-2. ${ }^{7}$

\footnotetext{
${ }^{6}$ See e.g. Jones and Yoo (2011) for a comparison of the Korean emission intensities to the ones of other OECD countries.

${ }^{7}$ The drop in FDI inflows in 2007 may be partly explained by a notification bias and a statistical effect of the unallocated sector-specific FDI data of the OECD.
} 
Figure-2: Development of Total FDI Inflows into Korea and Their Regional Distribution a, b

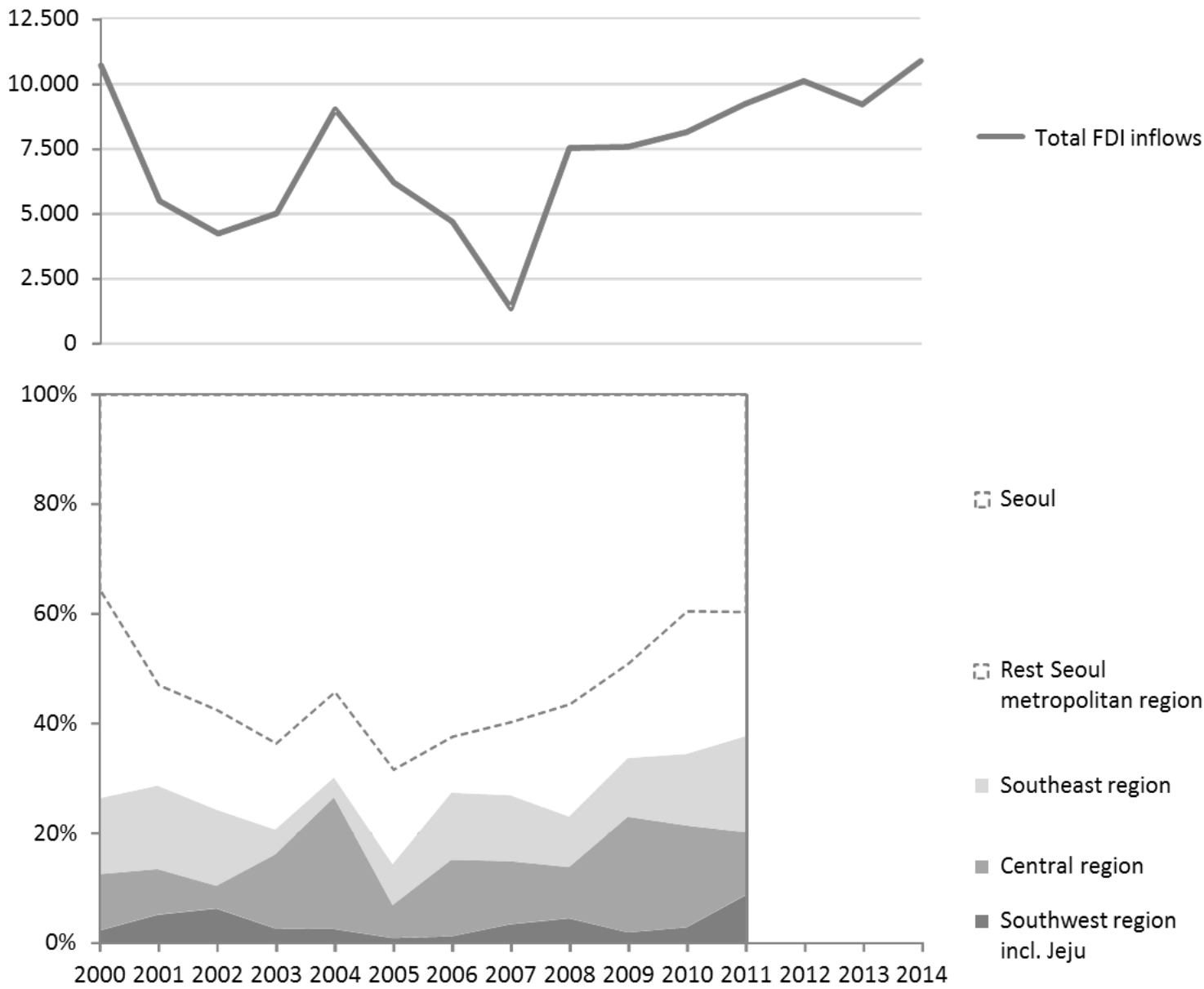

Note: ${ }^{\mathrm{a}}$ In billion Won 2005 prices and in percentages; ${ }^{\mathrm{b}}$ Self-prepared using OECD (2017) and KOTRA (2014)

As can be seen the majority of FDI inflows have been invested in the Seoul metropolitan region accounting for 74 and 62 percent in 2000 and 2011 respectively. ${ }^{8}$ Thereby, the largest share has been invested directly in Seoul. The Southeastern region, including leading industrial cities such as Busan and Ulsan, was the second most important investment destination in the years 2000 and 2011 accounting for 14 and 17 percent of the FDI inflows. Concerning the sectoral distribution large shares of FDI inflows have been invested in manufacturing and service sectors. While roughly 37 and 38 percent of the total FDI inflows were invested in manufacturing sectors in the years 2000 and 2011, the numbers of the service sectors amount to 38 and 50 percent. Below one percent can be attributed to the primary sector and the remaining share is unallocated (OECD 2017). During the period under consideration the distribution of FDI inflows with regards to the originating countries changed considerably. While foreign investments from European and Asian countries headed by Japanese firms rose to 39 and 37 percent respectively, the importance of American investors decreased to 22 percent (OECD 2017). With regards to the level of economic development, the FDI inflows originated mainly from other OECD countries, whose share increased from 65 to 77 percent between 2000 and 2011. The importance of FDI inflows from non-OECD countries declined respectively. For instance, only 1.5 percent of FDI inflows in 2011 originated from Mainland China vs. roughly 22 percent from Japan.

\footnotetext{
${ }^{8}$ The 16 provinces are allocated in four regions using the regional classification of Kim and Jeong (2003). Figure-4 in Appendix-B shows a corresponding map.
} 
However, despite the liberalization efforts, FDI inflows remain comparatively low on an international scale. Whereas FDI inflows on the world level ranged between 1.63 to 5.17 percent as a share of the world's gross domestic product during the years 2000 to 2011, the corresponding maximum value for Korea amounts to only 1.65 percent. ${ }^{9}$ Even the East Asian average of 2.23 percent is higher than the Korean maximum value (World Bank 2016). Hence, if foreign investments are indeed considered as an important pillar in Korea to stimulate economic growth and the adoption of environmentally friendly technologies, the efforts to attract FDI inflows may have to be intensified.

\section{Methodology}

This study aims at analyzing the relationship between FDI inflows and air pollution in Korea on the provincial level in order to make inferences on the role that FDI may play in Korea's green growth strategy. To ensure robustness of the results the emission levels of six air pollutants are analyzed, namely $\mathrm{CO}, \mathrm{NO}_{\mathrm{x}}, \mathrm{SO}_{\mathrm{x}}, \mathrm{TSP}, \mathrm{PM}_{10}$, and VOC. Following the reasoning of Copeland and Taylor (2004), the impact of FDI on air pollution emissions POLL is decomposed into a scale, a composition, and a technique effect:

$$
\ln P O L L_{i t}=\ln G D P_{i t}+\ln \left(\frac{V A_{I N D i t}}{G D P_{i t}}\right)+\ln \left(\frac{P O L L_{i t}}{V A_{I N D i t}}\right)
$$

In this identity the gross regional product GDP of province $i$ in year $t$ is commonly used to capture the scale effect. The ratio of the gross industrial value added $V A_{I N D}$ to the provinces' gross regional product measures the composition effect, i.e. the impact on air emissions through the change in the industrial structure. The technique effect is captured through the pollution intensity, which is calculated by dividing the total pollution emissions by the gross industrial value added. Apart from the pollution tax rate, the technique effect is influenced by additional factors, such as research and development expenditures on environmental conservation or technological innovations. Therefore, the pollution rate per industrial value added can be regarded as a more direct measure of the technique effect (Bao et al. 2011).

This research jointly analyzes the three channels through which FDI may affect the environment using a simultaneous equations model. Systems of simultaneous equations have often been applied to the FDI-environment nexus as they facilitate the joint modelling of the three effects along with the interactions between the partly endogenous variables (He 2006, Yang et al. 2013). Thereby, both the direct as well as the indirect impacts of FDI on the pollution emissions and a feedback effect of the pollution emissions on FDI are considered by adapting the methodology of Bao et al. (2011). This extension is regarded of particular importance to correctly evaluate the effect of FDI for a highly developed economy like Korea. Korea's economy leverages an advanced technological infrastructure where influences may not be straightforward but rather come into effect through a network of interactions. Figure-3 in Appendix-A summarizes the different channels of the impacts of FDI on air emissions. In the following each channel is further detailed and subsequently merged into one system of simultaneous equations.

\footnotetext{
${ }^{9}$ To ensure comparability the ratios are taken from the World Bank (2016). The respective maximum value for Korea in this study's used dataset amounts to 1.55 percent in the year 2000.
} 


\section{IV.I Scale Effect}

The direct scale effect of FDI is captured by estimating the impact of FDI on the gross regional product:

$$
\begin{gathered}
\ln G D P_{i t}=\alpha_{0}+\alpha_{1} \ln F D I_{i t}+\alpha_{2} \ln K_{i t}+\alpha_{3} \ln L_{i t}+\alpha_{4} \ln H_{i t}+\alpha_{5} \ln P O L L_{i t} \\
+\eta_{r}+\eta_{\text {City }}+\eta_{t}+\varepsilon_{i t}
\end{gathered}
$$

Besides FDI, the gross regional product is a function of the province-specific physical capital stock $K$ and labor $L$, which is measured as the total annual working hours of the employed personal. The stock of human capital $H$ is approximated using the educational attainment of the economically active population (Barro and Lee 2013). In order to capture a feedback effect of air pollution on economic growth, air emissions POLL are included as an explanatory variable. The estimated coefficient can either be positive or negative. At an initially low level of pollution a moderate increase in air emissions may, all things being equal, result in a higher output as firms can lower pollution abatement expenditures and the costs of environmental degradation are comparatively low. However, once a threshold level of pollution is reached further increases in air emissions may have a negative effect on economic growth given the large associated environmental damages and necessary costs for restoration. Regional differences are captured by adding region-specific fixed effects $\eta_{r}$. For that reason, the regional classification of Kim and Jeong (2003) is adopted, who cluster the Korean provinces based on income inequalities into four regions. The four regions are the Seoul metropolitan region (Incheon, Seoul, Gyeonggi), the central region (Daejeon, Chungcheongbuk, Chungcheongnam, Gangwon), the southeast region (Busan, Daegu, Ulsan, Gyeongsangbuk, Gyeongsangnam), and the southwest region (Gwangju, Jeollabuk, Jeollanam) where Jeju province is added. Figure-4 in Appendix-B shows a respective map of the allocation of the provinces. Given the long-term efforts of controlling the growth in particular in the Greater Seoul area and in the metropolitan cities to ensure a balanced national development, a fixed-effect for the seven self-governing cities $\eta_{\text {City }}$ is added. Finally, $\eta_{t}$ captures year fixed effects and $\varepsilon$ represents the error term.

\section{IV.II Composition Effect}

The direct impact of FDI on industrial composition is estimated by the following equation:

$$
\begin{aligned}
\ln \left(\frac{V A_{\text {INDit }}}{G D P_{i t}}\right)=\beta_{0} & +\beta_{1} \ln F D I_{i t}+\beta_{2} \ln R \& D_{i t}+\beta_{3} \ln \left(\frac{K_{i t}}{L_{i t}}\right)+\beta_{4} \ln \left(\frac{G D P_{i t}}{P O P_{i t}}\right) \\
& +\beta_{5} \ln R O A D_{i t}+\eta_{r}+\eta_{\text {Seoul }}+\eta_{\text {Jeju }}+\eta_{t}+\varepsilon_{i t}
\end{aligned}
$$

Following Bao et al. (2011) research and development expenditures $R \& D$ are included as an explanatory variable, because the development of technologies and innovations may foster the adjustment of regional industrial structures. A higher capital-labor ratio $K / L$ is, on average, associated with a larger contribution of industry sectors to the provinces' value added and, consequently, higher air pollution. Moreover, per capita income GDP/POP is often included as an additional driver of the industrial composition (Wang and Jin 2007, Yang et al. 2013). In an early stage of development a rise in income may reflect rapid industrialization and the growing demand for manufactured goods relative to agricultural goods, which is often accompanied with a rise in pollution. With a rising income the importance of industrial sector decreases relative to service sector and the demand for a cleaner environment tends to increase. Thus, the coefficient of per capita income may be either positive or negative. ROAD represents the length of paved roads and is added in order to capture the importance of 
infrastructure development for industrial activities. Given that the secondary sector adds a significantly lower share to Seoul's and Jeju's gross regional product, the additional respective fixed effects $\eta_{\text {Seoul }}$ and $\eta_{\text {Jeju }}$ are included besides the regular region-specific and year fixed effects.

\section{IV.III Technique Effect}

The direct technique effect of FDI is captured by regressing FDI on the air pollution intensity:

$$
\begin{aligned}
\ln \left(\frac{P O L L_{i t}}{V A_{\text {INDit }}}\right)=\gamma_{0} & +\gamma_{1} \ln G O V_{i t}+\gamma_{2} \ln R \& D_{i t}+\gamma_{3} \ln F D I_{i t}+\gamma_{4} \ln \left(\frac{K_{i t}}{L_{i t}}\right)+\gamma_{5} \ln H_{i t} \\
& +\gamma_{6} \ln \left(\frac{P O P_{i t}}{A R E A_{i}}\right)+\gamma_{7} \ln \left(\frac{G D P_{i t}}{P O P_{i t}}\right)+\gamma_{8} \ln I N S P_{i t-1}+\gamma_{9} \ln V I O L_{i t-1} \\
& +\gamma_{10} \ln P O L L_{i t-1}+\eta_{r}+\eta_{\text {Seoul }}+\eta_{\text {Jeju }}+\eta_{t}+\varepsilon_{i t}
\end{aligned}
$$

Besides research and development expenditures $R \& D$, government expenditures on environmental protection $G O V$ are seen as an important effort of the host country to reduce air pollution. ${ }^{10}$ As pollution-intensive sectors are relatively capital-intensive (Cole and Elliott 2003), the capital-labor ratio $K / L$ is included in the specification. The coefficient of both educational attainment, which measures human capital accumulation $H$, and of per capita income $G D P / P O P$, which reflects the stage of regional economic development, is expected to be negative. A larger educational attainment is associated with an increasing demand for environmental quality. The same may also be true for a larger income per capita. In addition, a higher income level is also an indication for a more advanced regional economic development, i.e. more funds can be spent on environmental protection and pollution abatement (Bao et al. 2011). With a rising population density POP/AREA the detrimental effects of air pollution are likely to affect more people and, consequently, the pressure on regulators to rapidly reduce the air pollution intensities increases. In order to analyze the impact of regulation on the air pollution intensity in more detail, two complementary determinants of environmental policy stringency are added, namely the number of inspections of air pollution emitting facilities $I N S P_{t-1}$ and the respective detected violations per inspection VIOLt-1. As the regulatory effect is likely to occur with a delay (Cole and Elliot 2003), the variables are lagged by one period. Thereby, a larger number of inspections and a higher share of detected violations are interpreted as a stricter air emissions policy enforcement. Moreover, one-period lagged air pollution emissions $P O L L_{t-1}$ are included to capture potential technological path dependencies. Following a similar argumentation as in the composition effect, additional fixed effects for Seoul and Jeju are included along with region-specific and year fixed effects. Specifically, the former fixed effects are used to correct for the two provinces' diverging composition of sectors and, hence, potential significant deviations in air pollution intensities.

\section{IV.IV Capital Accumulation}

Besides the direct effects $\alpha_{1}, \beta_{1}$, and $\gamma_{3}$, FDI can influence the three channels presented beforehand indirectly by changing the domestic capital stock $K$, another explanatory variable in equation-2, 3, and 4. Therefore, the effect of FDI on capital accumulation is specified using the following equation:

\footnotetext{
${ }_{10}$ As province-specific statistics on government expenditures for environmental protection only are, to the authors' knowledge, not provided by the National Statistics Office of Korea (KOSTAT), the government expenditures on health, welfare, and the environment are used as a proxy.
} 


$$
\ln K_{i t}=\delta_{0}+\delta_{1} \ln F D I_{i t}+\delta_{2} \ln G D P_{i t-1}+\delta_{3} \ln G D P_{i t-2}+\eta_{i}+\eta_{t}+\varepsilon_{i t}
$$

Thereby, the estimated sign of the coefficient $\delta_{l}$ can either be positive or negative. While the former can, for instance, be the case when FDI inflows entail domestic investments of subcontractors, the latter may be true if FDI inflows crowd out domestic investments. Apart from FDI inflows, the domestic capital accumulation is estimated to be a function of the oneand two-year lagged gross regional products $G D P_{t-1}$ and $G D P_{t-2}$. Both lagged variables are added to capture the effect of economic fluctuations and the macroeconomic environment (Bao et al. 2011). In addition, province-specific fixed effects $\eta_{i}$ along with year fixed effects are used to account for the diverse distribution of physical capital stocks across provinces and variability over time.

\section{IV.V Determinants of FDI Inflows}

As has been shown in previous studies, FDI inflows may be simultaneously determined by several of the dependent variables of the above detailed equations- 2 to 5 . For instance, FDI inflows are expected to increase the gross regional product GDP through the direct scale effect. Yet, at the same time a growing economy may attract foreign investors and, hence, leads to a rise in FDI inflows. In order to account for this potential endogeneity problem, the determinants of FDI inflows are estimated using the following equation:

$$
\begin{array}{r}
\ln F D I_{i t}=\lambda_{0}+\lambda_{1} \ln F D I_{i t-1}+\lambda_{2} \ln W A G E_{i t}+\lambda_{3} \ln H_{i t}+\lambda_{4} \ln R O A D_{i t} \\
+\lambda_{5} \ln I N S P_{i t-1}+\lambda_{6} \ln V I O L_{i t-1}+\eta_{r}+\eta_{C i t y}+\eta_{t}+\varepsilon_{i t}
\end{array}
$$

Here, the FDI inflows are explained by the one-period lagged FDI inflows $F D I_{t-1}$, which capture to what extent previous foreign investments and the self-accumulation of FDI inflows are important for current foreign investments. The role of labor costs is analyzed by including the average annual salary of employed personal WAGE. Similarly, the stock of human capital $H$ is added to test the relevance of regional differences in educational attainment for FDI inflows.

In order to elaborate on the question whether a stricter environmental policy discourages or attracts foreign investments in Korea, the two lagged policy variables $I N S P_{t-1}$ and $V I O L_{t-1}$ are included. The estimated signs of the coefficients may vary depending on the underlying nature of the foreign investments. For instance, if the FDI inflows are rather green, a stricter environmental policy will likely attract foreign investments and, thus, the expected coefficients are positive. The importance of infrastructure development for foreign investments is captured with the help of the length of paved roads $R O A D$. In order to account for further regional differences in the distribution of FDI inflows and the tendency of foreign investments in urban areas, both region-specific fixed effects and a fixed effect for the seven self-governing cities are added. Finally, the year fixed effects again capture variability of the regressand over time.

\section{IV.VI System of Simultaneous Equations}

All in all, the impact of FDI inflows on air pollution in Korea is simultaneously determined through a system of the six equations- 1 to 6 : 


$$
\begin{aligned}
& \int \ln P O L L_{i t}=\ln G D P_{i t}+\ln \left(\frac{V A_{\text {INDit }}}{G D P_{i t}}\right)+\ln \left(\frac{P O L L_{i t}}{V A_{\text {INDit }}}\right) \\
& \ln G D P_{i t}=\alpha_{0}+\alpha_{1} \ln F D I_{i t}+\alpha_{2} \ln K_{i t}+\alpha_{3} \ln L_{i t}+\alpha_{4} \ln H_{i t}+\alpha_{5} \ln P O L L_{i t} \\
& +\eta_{r}+\eta_{\text {City }}+\eta_{t}+\varepsilon_{i t} \\
& \ln \left(\frac{V A_{I N D i t}}{G D P_{i t}}\right)=\beta_{0}+\beta_{1} \ln F D I_{i t}+\beta_{2} \ln R \& D_{i t}+\beta_{3} \ln \left(\frac{K_{i t}}{L_{i t}}\right)+\beta_{4} \ln \left(\frac{G D P_{i t}}{P O P_{i t}}\right) \\
& +\beta_{5} \ln R O A D_{i t}+\eta_{r}+\eta_{\text {Seoul }}+\eta_{\text {Jeju }}+\eta_{t}+\varepsilon_{i t} \\
& \ln \left(\frac{P O L L_{i t}}{V A_{I N D i t}}\right)=\gamma_{0}+\gamma_{1} \ln G O V_{i t}+\gamma_{2} \ln R \& D_{i t}+\gamma_{3} \ln F D I_{i t}+\gamma_{4} \ln \left(\frac{K_{i t}}{L_{i t}}\right)+\gamma_{5} \ln H_{i t} \\
& +\gamma_{6} \ln \left(\frac{P O P_{i t}}{A R E A_{i}}\right)+\gamma_{7} \ln \left(\frac{G D P_{i t}}{P O P_{i t}}\right)+\gamma_{8} \ln I N S P_{i t-1}+\gamma_{9} \ln V I O L_{i t-1} \\
& +\gamma_{10} \ln P O L L_{i t-1}+\eta_{r}+\eta_{\text {Seoul }}+\eta_{\text {Jeju }}+\eta_{t}+\varepsilon_{i t} \\
& \ln K_{i t}=\delta_{0}+\delta_{1} \ln F D I_{i t}+\delta_{2} \ln G D P_{i t-1}+\delta_{3} \ln G D P_{i t-2}+\eta_{i}+\eta_{t}+\varepsilon_{i t} \\
& \ln F D I_{i t}=\lambda_{0}+\lambda_{1} \ln F D I_{i t-1}+\lambda_{2} \ln W A G E_{i t}+\lambda_{3} \ln H_{i t}+\lambda_{4} \ln R O A D_{i t} \\
& +\lambda_{5} \ln I N S P_{i t-1}+\lambda_{6} \ln V I O L_{i t-1}+\eta_{r}+\eta_{\text {City }}+\eta_{t}+\varepsilon_{i t}
\end{aligned}
$$

The identity-1 decomposes the environmental impact of FDI into a scale, composition, and technique effect, i.e. equation-2, 3, and 4 respectively. Equation-5 estimates how FDI inflows affect the domestic capital accumulation in Korea. Furthermore, equation- 6 analyzes the determinants of foreign investments in Korea. As can be seen from the system of equations, the equations share several explanatory variables and there exist interdependencies between the three pollution channels. Figure-3 in Appendix-A provides a graphic summary of how the different channels are interlinked. The total effect of FDI inflows on Korean air emissions consists of direct and indirect effects. First, FDI inflows directly impact air pollution through the scale, composition, and technique effect, which are captured by the coefficients $\alpha_{1}, \beta_{l}$, and $\gamma_{3}$. Second, FDI inflows indirectly influence air pollution by changing the domestic capital stock via $\delta_{1}$, which in turn also impacts the three effects through $\alpha_{2}, \beta_{3}$, and $\gamma_{4}$. Third, FDI alters the per capita income through its impact on the gross regional product GDP, i.e. the scale effect. Consequently, the change in per capita income also indirectly influences the industrial composition and the pollution intensity in the form of $\beta_{4}$ and $\gamma_{7}$. Lastly, the framework includes a feedback effect of air pollution on the gross regional product captured through $\alpha_{5}$.

Given that several equations in the system of structural equations contain potentially endogenous variables among the explanatory variables, following earlier literature the three-stage least squares (3SLS) estimator is applied (Bao et al. 2011, Yang et al. 2013). Zellner and Theil (1962) first introduced the 3SLS estimator that combines seemingly unrelated regressions (SUR) with two-stage least squares (2SLS). 3SLS allows controlling for the potentially endogenous variables and improves the efficiency of 2SLS by considering the correlations between the error terms across the different equations. Unless not specified differently, 3SLS explicitly considers all dependent variables as endogenous and takes the remaining variables as instruments. Hence, in this paper's simultaneous equations model the FDI inflows $F D I_{i t}$, gross regional product $G D P_{i t}$, gross industrial value added $V A_{I N D}$ it, physical capital stock $K_{i t}$, and air emissions $P O L L_{i t}$ are treated as endogenous. Moreover, equations- 2 to 6 include either region- or province-specific fixed effects along with year fixed 
effects to control for heterogeneity of the panel data. This helps avoiding heteroskedastic error terms and, hence, obtaining results that are comparable to a multiple-equation generalized method of moments (GMM) estimation. ${ }^{11}$

\section{Data}

To estimate the system of simultaneous equations this paper utilizes panel data for the 16 Korean provinces and self-governing cities from 2000 to 2011. The analyzed time period is determined by the availability of data on the regional distribution of FDI inflows, which is not publicly available. This information is provided by the Korean Trade-Investment Promotion Agency (KOTRA 2014) and combined with the country-specific FDI inflows of the OECD (2017) to compute the provincial level FDI inflows. The majority of the remaining variables are determined based on data of the Korean Statistical Information Service (KOSIS 2014), the statistical database operated by the National Statistics Office of Korea (KOSTAT). Complementary data on sector-specific capital stocks are obtained from the World InputOutput Database (WIOD 2014) and air emissions are used from the Korean National Institute of Environmental Research (NIER 2018).

As provincial level data on the capital stock and the level of human capital are not available, both variables need to be estimated. With regards to the former, base year capital stocks are approximated following Derbyshire et al. (2013), who calculate regional base year values based on national level industry-specific capital stocks for different asset types and the regional distribution of value added in each industry. The provincial level capital stocks of the remaining years can be determined with the help of the perpetual inventory method utilizing province-specific data on fixed capital formation and depreciation. Concerning the latter, educational attainment is used to approximate human capital accumulation (Barro and Lee 2013). Specifically, the average number of education years of the provinces' economically active population is calculated with the help of province-specific information on their highest level of education. For that reason, the educational attainment of the lower, middle, and high school is set to six, nine, and twelve years respectively and that of college and university graduates to 16 and 19 years. Lastly, all monetary values are converted into Korean Won in 2005 prices using province-specific deflators. An overview of the final variables, their units of measurement, as well as the regular descriptive statistics can be found in Table- 8 and 9 in Appendix-C.

\section{Results and their Discussion}

In order to obtain results for the simultaneous equations model, it is necessary to estimate the five equations- 2 to 6 using the 3SLS estimator. The estimated coefficients are then used to determine the identity- 1 that reveals the total environmental effect of FDI inflows. In the following the estimation results of the five equations are presented one after the other. Afterwards the combined effects of FDI inflows on air pollution are determined and discussed.

\section{VI.I Estimation of Scale Effect}

Table-1 exhibits the regression output for the scale effect. The direct scale effect of FDI is estimated to be significantly positive for all six air pollutants. The coefficients range between 0.07 and 0.17 implying that a one percent increase in FDI inflows coincides with a 0.07 to 0.17 percent increase in the gross regional product. Given the relatively small values of FDI inflows, which on the country level range between 0.14 and 1.55 percent as a share of the

\footnotetext{
${ }^{11}$ Given the limited degrees of freedom this paper favors 3SLS over the multiple-equation GMM. As a special case of multiple-equation GMM, 3SLS uses the same instruments across all equations, yet requiring conditional homoscedasticity.
} 
gross domestic product during the analyzed time period, FDI can be regarded as an important driving force of economic growth. In addition, the scale effect is further increased indirectly in particular through the impact of FDI on domestic capital accumulation.

Compared to the factor inputs, namely physical capital $K$, labor $L$, and human capital $H$, the absolute impact of FDI on economic growth is generally smaller. In this regard physical capital is more important than the other two factors. This corresponds to Korea's industry structure and the dominant role of conglomerates, which from the 1980s onwards specialized in the production and trade of capital-intensive goods (Chow 2012). Besides that, it becomes apparent that the coefficients of labor and human capital have opposite signs, whereas in terms of absolute values the estimated coefficient of human capital is mainly significantly larger. This indicates that merely increasing the annual working hours that are on an international scale already above average does not add to growth of the gross regional product. Instead rather educated personal is needed for Korea to continue on its growth path. For instance, a high level of human capital is needed to change Korea's economic paradigm into an innovate, entrepreneurial "creative economy" focusing on fields such as green growth (MOSF 2013).

Table-1: Regression Results of Scale Effect

\begin{tabular}{|c|c|c|c|c|c|c|c|c|c|c|c|c|}
\hline \multicolumn{13}{|c|}{ 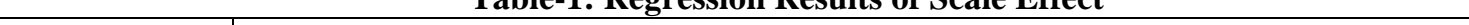 } \\
\hline & \multicolumn{12}{|c|}{$\ln \mathbf{G D P}_{i t}$} \\
\hline & \multicolumn{2}{|l|}{$\mathrm{CO}_{i t}$} & \multicolumn{2}{|c|}{$S \boldsymbol{O}_{X i t}$} & \multicolumn{2}{|c|}{$N O_{X i t}$} & \multicolumn{2}{|c|}{$T S P_{i t}$} & \multicolumn{2}{|c|}{$P M_{10}$ it } & \multicolumn{2}{|c|}{$V O C_{i t}$} \\
\hline \multirow[t]{2}{*}{$\ln F D I_{i t}$} & 0.072 & $* * *$ & 0.168 & $* * *$ & 0.146 & $* * *$ & 0.175 & $* * *$ & 0.174 & $* * *$ & 0.091 & $* * *$ \\
\hline & $(0.013)$ & & $(0.015)$ & & $(0.014)$ & & $(0.016)$ & & $(0.016)$ & & $(0.012)$ & \\
\hline \multirow[t]{2}{*}{$\ln K_{i t}$} & 0.960 & $* * *$ & 0.979 & $* * *$ & 0.950 & $* * *$ & 0.999 & $* * *$ & 0.999 & $* * *$ & 0.892 & $* * *$ \\
\hline & $(0.063)$ & & $(0.073)$ & & $(0.067)$ & & $(0.076)$ & & $(0.076)$ & & $(0.047)$ & \\
\hline \multirow[t]{2}{*}{$\ln L_{i t}$} & -0.520 & $* * *$ & -0.434 & $* * *$ & -0.436 & $* * *$ & -0.464 & $* * *$ & -0.467 & $* * *$ & -0.338 & $* * *$ \\
\hline & $(0.053)$ & & $(0.074)$ & & $(0.063)$ & & $(0.076)$ & & $(0.075)$ & & $(0.047)$ & \\
\hline \multirow[t]{2}{*}{$\ln H_{i t}$} & 0.594 & $* *$ & 1.296 & $* * *$ & 1.216 & $* * *$ & 1.119 & $* * *$ & 1.093 & $* * *$ & 0.996 & $* * *$ \\
\hline & $(0.236)$ & & $(0.369)$ & & $(0.309)$ & & $(0.357)$ & & $(0.354)$ & & $(0.203)$ & \\
\hline \multirow[t]{2}{*}{$\ln P O L L_{i t}$} & 0.363 & $* * *$ & 0.040 & $* *$ & 0.126 & $* * *$ & 0.025 & $*$ & 0.028 & $*$ & 0.210 & $* * *$ \\
\hline & $(0.074)$ & & $(0.016)$ & & $(0.031)$ & & $(0.014)$ & & $(0.016)$ & & $(0.019)$ & \\
\hline \multirow[t]{2}{*}{ Central } & -0.200 & $* * *$ & -0.208 & $* * *$ & -0.224 & $* * *$ & -0.228 & $* * *$ & -0.229 & $* * *$ & -0.123 & $* * *$ \\
\hline & $(0.044)$ & & $(0.056)$ & & $(0.050)$ & & $(0.058)$ & & $(0.058)$ & & $(0.038)$ & \\
\hline \multirow[t]{2}{*}{ Southeast } & 0.058 & $*$ & 0.103 & $* *$ & 0.095 & $* *$ & 0.118 & $* *$ & 0.117 & $* *$ & 0.051 & $*$ \\
\hline & $(0.035)$ & & $(0.045)$ & & $(0.041)$ & & $(0.048)$ & & $(0.048)$ & & $(0.029)$ & \\
\hline \multirow[t]{2}{*}{ Southwest } & -0.054 & & 0.013 & & 0.011 & & -0.003 & & -0.007 & & -0.033 & \\
\hline & $(0.053)$ & & $(0.067)$ & & $(0.060)$ & & $(0.068)$ & & $(0.067)$ & & $(0.041)$ & \\
\hline \multirow[t]{2}{*}{ City } & -0.108 & $* * *$ & -0.150 & $* * *$ & -0.107 & $* * *$ & -0.161 & $* * *$ & -0.159 & $* * *$ & -0.135 & $* * *$ \\
\hline & $(0.031)$ & & $(0.041)$ & & $(0.038)$ & & $(0.043)$ & & $(0.043)$ & & $(0.026)$ & \\
\hline \multirow[t]{2}{*}{ Constant } & 4.778 & $* * *$ & 5.212 & $* * *$ & 4.866 & $* * *$ & 5.813 & $* * *$ & 5.887 & $* * *$ & 4.749 & $* * *$ \\
\hline & $(0.732)$ & & $(0.917)$ & & $(0.813)$ & & $(0.865)$ & & $(0.856)$ & & $(0.524)$ & \\
\hline $\mathrm{R}^{2}$ adjusted & 0.970 & & 0.915 & & 0.933 & & 0.908 & & 0.908 & & 0.969 & \\
\hline Observations & 192 & & 192 & & 192 & & 192 & & 192 & & 192 & \\
\hline
\end{tabular}

Moreover, Table-1 provides information on the feedback effect of pollution emissions POLL on the gross regional product. Given that all coefficients are positive and significant, pollution 
emissions can be regarded as another input factor. ${ }^{12}$ Yet, the magnitude of the elasticities differs across pollutants. Rather low and less significant feedback effects are estimated for TSP and $\mathrm{PM}_{10}$, the pollutants that experienced the highest growth rates during the analyzed time period. This indicates that the respective air emission levels are closer to the threshold level where further increases negatively impact economic growth. Regional differences in economic growth are captured through the fixed effects of the regions and the self-governing cities. As the gross regional product is specified in logarithmic form, the coefficients can be interpreted by taking the exponential. While the southwestern region does not reveal significant differences compared to the Seoul metropolitan area, the gross regional product of the central region is between 12 and 20 percent lower and the one of the southeastern region between 5 and 13 percent higher. Finally, after controlling for factor inputs and other fixed effects the coefficients of the self-governing cities are, as expected, all significantly negative and range between -0.11 and -0.16 .

\section{VI.II Estimation of Composition Effect}

The regression output for the composition effect is shown in Table-2. For all six air emissions the direct composition effect of FDI is estimated to be significantly positive. According to the coefficients the share of industrial value added relative to the gross regional product will increase by 0.03 to 0.05 percent with a one percent rise in FDI inflows. This rather small impact seems reasonable given that during the period under consideration the FDI inflows were not only concentrated in the manufacturing sectors, but also considerable amounts have been invested in the service sectors. As FDI inflows into secondary sector do not amount to the majority of allocated FDI inflows, it indicates that during the period 2000 to 2011 one Won of FDI in the secondary sector created a slightly higher value added than one Won of FDI in primary and tertiary sectors. Apart from that, secondary sectors may benefit above average from FDI in other sectors through linkages in the value chain. Besides FDI inflows research and development expenditures $R \& D$ foster the regional industrial development as positive and highly significant coefficients are reported ranging between 0.07 and 0.08 .

Contrary to that, the coefficients of the capital-labor ratio $K / L$ are estimated to be negative. This unexpected sign of the coefficient may be explained by the relationship between the capital labor-ratio and per capita income GDP/POP and by an increasing dispersion of capital-labor ratios. On the one hand, Leonardi (2007) has detected a significant correlation between the capital-labor ratio and differences in employee's income. Consequently, including both predictors in a system of equations may impact these variables' coefficient estimate while not influencing the reliability of the model as a whole. On the other hand, previous literature has observed an increasing dispersion of the capital-labor ratios of industry firms (Caselli 1999, Leonardi 2007). Given that emissions-intensive industries and rather clean industries are affected by this dispersion, regressing the capital-labor ratio on pollution intensity may for certain samples result in counterintuitive signs of the coefficient estimates. As this study's coefficient estimates are, despite the unexpected sign, robust for the six different air pollutants, both variables are kept in the equation in order to avoid potentially biased estimates. ${ }^{13}$

\footnotetext{
12 The estimates are in line with the practice of treating pollution emissions as an input factor, which is an often applied modeling assumption in the trade and environment context - see for example Copeland and Taylor (2003).

${ }^{13}$ It should be noted that if the per capita income is dropped from the composition equation (3), the capital-labor coefficient estimates will change to the expected positive and significant values. Yet, at the same time the explanatory power will significantly drop indicating the omission of a relevant variable.
} 
Table-2: Regression Results of Composition Effect

\begin{tabular}{|c|c|c|c|c|c|c|c|c|c|c|c|c|}
\hline & \multicolumn{12}{|c|}{$\ln V A_{I N D} i t / G D P_{i t}$} \\
\hline & \multicolumn{2}{|c|}{$\mathrm{CO}_{i t}$} & \multicolumn{2}{|c|}{$S O_{X}$ it } & \multicolumn{2}{|c|}{$N O_{X i t}$} & \multicolumn{2}{|c|}{$T S P_{i t}$} & \multicolumn{2}{|c|}{$P M_{10}$ it } & \multicolumn{2}{|c|}{$V O C_{i t}$} \\
\hline \multirow[t]{2}{*}{$\ln F D I_{i t}$} & 0.028 & $* *$ & 0.034 & $* *$ & 0.049 & $* * *$ & 0.033 & $*$ & 0.033 & $* *$ & 0.050 & $* * *$ \\
\hline & $(0.014)$ & & $(0.017)$ & & $(0.016)$ & & $(0.017)$ & & $(0.017)$ & & $(0.016)$ & \\
\hline \multirow[t]{2}{*}{$\ln R \& D_{i t}$} & 0.076 & $* * *$ & 0.072 & $* * *$ & 0.070 & $* * *$ & 0.073 & *** & 0.073 & $* * *$ & 0.072 & $* * *$ \\
\hline & $(0.013)$ & & $(0.014)$ & & $(0.014)$ & & $(0.014)$ & & $(0.014)$ & & $(0.014)$ & \\
\hline \multirow[t]{2}{*}{$\ln K_{i t} / L_{i t}$} & -2.295 & $* * *$ & -2.271 & $* * *$ & -2.263 & $* * *$ & -2.270 & $* * *$ & -2.266 & $* * *$ & -2.325 & $* * *$ \\
\hline & $(0.136)$ & & $(0.139)$ & & $(0.135)$ & & $(0.137)$ & & $(0.137)$ & & $(0.135)$ & \\
\hline \multirow[t]{2}{*}{$\ln G D P_{i t} / P O P_{i t}$} & 2.092 & $* * *$ & 2.066 & $* * *$ & 2.052 & $* * *$ & 2.068 & $* * *$ & 2.065 & $* * *$ & 2.099 & $* * *$ \\
\hline & $(0.074)$ & & $(0.077)$ & & $(0.075)$ & & $(0.076)$ & & $(0.076)$ & & $(0.075)$ & \\
\hline \multirow[t]{2}{*}{$\ln R O A D_{i t}$} & 0.036 & $*$ & 0.039 & $*$ & 0.025 & & 0.041 & $* *$ & 0.040 & $*$ & 0.021 & \\
\hline & $(0.019)$ & & $(0.021)$ & & $(0.020)$ & & $(0.021)$ & & $(0.021)$ & & $(0.020)$ & \\
\hline \multirow[t]{2}{*}{ Central } & 0.108 & $* *$ & 0.115 & $* * *$ & 0.137 & $* * *$ & 0.116 & $* * *$ & 0.116 & $* * *$ & 0.143 & $* * *$ \\
\hline & $(0.042)$ & & $(0.043)$ & & $(0.043)$ & & $(0.043)$ & & $(0.043)$ & & $(0.043)$ & \\
\hline \multirow[t]{2}{*}{ Southeast } & 0.151 & $* * *$ & 0.163 & $* * *$ & 0.185 & $* * *$ & 0.163 & $* * *$ & 0.164 & $* * *$ & 0.184 & $* * *$ \\
\hline & $(0.040)$ & & $(0.041)$ & & $(0.041)$ & & $(0.041)$ & & $(0.041)$ & & $(0.041)$ & \\
\hline \multirow[t]{2}{*}{ Southwest } & 0.275 & $* * *$ & 0.285 & $* * *$ & 0.319 & $* * *$ & 0.286 & $* * *$ & 0.286 & $* * *$ & 0.327 & $* * *$ \\
\hline & $(0.050)$ & & $(0.052)$ & & $(0.052)$ & & $(0.051)$ & & $(0.051)$ & & $(0.052)$ & \\
\hline \multirow[t]{2}{*}{ Seoul } & -1.276 & **** & -1.276 & $* * *$ & -1.291 & $* * *$ & -1.274 & $* * *$ & -1.276 & $* * *$ & -1.281 & $* * *$ \\
\hline & $(0.076)$ & & $(0.080)$ & & $(0.078)$ & & $(0.079)$ & & $(0.079)$ & & $(0.077)$ & \\
\hline \multirow[t]{2}{*}{ Јеји } & -1.841 & $* * *$ & -1.825 & $* * *$ & -1.788 & $* * *$ & -1.826 & $* * *$ & -1.824 & $* * *$ & -1.791 & $* * *$ \\
\hline & $(0.059)$ & & $(0.063)$ & & $(0.062)$ & & $(0.063)$ & & $(0.063)$ & & $(0.062)$ & \\
\hline \multirow[t]{2}{*}{ Constant } & -14.553 & $* * *$ & -14.403 & $* * *$ & -14.253 & $* * *$ & -14.451 & $* * *$ & -14.434 & $* * *$ & -14.468 & $* * *$ \\
\hline & $(0.427)$ & & $(0.448)$ & & $(0.444)$ & & $(0.446)$ & & $(0.446)$ & & $(0.445)$ & \\
\hline $\mathrm{R}^{2}$ adjusted & 0.964 & & 0.963 & & 0.958 & & 0.963 & & 0.963 & & 0.958 & \\
\hline Observations & 192 & & 192 & & 192 & & 192 & & 192 & & 192 & \\
\hline
\end{tabular}

Given the positive and significant coefficients a rise in per capita income $G D P / P O P$ coincides with a rise of the share of industrial value added. The coefficient estimates of this simultaneous relationship highlight the importance of the industrial sector with regards to value and income creation. However, as noted above, the coefficients of per capita income demand careful interpretation. Finally, while the regional fixed effects show significant dispersion among the provinces' industrial composition, the positive and mostly significant coefficients of the variable $R O A D$ capture the importance of a developed infrastructure for the advancement of industrial activities.

\section{IV.III Estimation of Technique Effect}

The estimation results for the technique effect are presented in Table-3. As can be seen, FDI inflows seem to have a limited direct technique effect on air pollution. While for five out of six air pollutants the coefficients are estimated to be negative, the coefficient is only highly significant in the case of VOC. Apart from a positive insignificant value for $\mathrm{NO}_{\mathrm{x}}$, the estimated coefficients range between -0.02 and -0.11 . Thus, in the case of VOC a 1 percent rise in FDI inflows corresponds with a 0.11 percent reduction in the emissions level per industrial value added. ${ }^{14}$ To a limited degree foreign investments seem to directly result in a

\footnotetext{
${ }^{14}$ The use of solvents and fossil fuels are major anthropogenic sources of VOC.
} 
clean-up of the average capital base through the implementation of new technologies and production processes.

Table-3: Regression Results of Technique Effect

\begin{tabular}{|c|c|c|c|c|c|c|c|c|c|c|c|c|}
\hline \multirow[b]{3}{*}{$\ln G O V_{i t}$} & \multicolumn{12}{|c|}{$\ln P O L L_{i t} / V A_{I N D}$ it } \\
\hline & \multicolumn{2}{|c|}{$\mathrm{CO}_{\text {it }}$} & \multicolumn{2}{|c|}{$S O_{X i t}$} & \multicolumn{2}{|c|}{$N O_{X}$ it } & \multicolumn{2}{|c|}{$T S P_{i t}$} & \multicolumn{2}{|c|}{$P M_{10}$ it } & \multicolumn{2}{|c|}{$V O C_{i t}$} \\
\hline & -0.553 & $* * *$ & -0.895 & $* * *$ & -0.756 & $* * *$ & -0.774 & $* * *$ & -0.762 & $* * *$ & -0.649 & $* * *$ \\
\hline & $(0.069)$ & & $(0.082)$ & & $(0.064)$ & & $(0.130)$ & & $(0.120)$ & & $(0.060)$ & \\
\hline \multirow[t]{2}{*}{$\ln R \& D_{i t}$} & -0.096 & $* * *$ & -0.142 & $* * *$ & -0.128 & $* * *$ & -0.159 & $* * *$ & -0.147 & $* * *$ & -0.076 & $* * *$ \\
\hline & $(0.018)$ & & $(0.031)$ & & $(0.021)$ & & $(0.046)$ & & $(0.041)$ & & $(0.020)$ & \\
\hline \multirow[t]{2}{*}{$\ln F D I_{i t}$} & -0.023 & & -0.024 & & 0.012 & & -0.022 & & -0.027 & & -0.113 & $* * *$ \\
\hline & $(0.020)$ & & $(0.036)$ & & $(0.025)$ & & $(0.051)$ & & $(0.047)$ & & $(0.025)$ & \\
\hline \multirow[t]{2}{*}{$\ln K_{i t} / L_{i t}$} & 2.256 & *** & 2.931 & $* * *$ & 2.627 & $* * *$ & 3.504 & $* * *$ & 3.498 & $* * *$ & 1.935 & $* * *$ \\
\hline & $(0.154)$ & & $(0.279)$ & & $(0.187)$ & & $(0.343)$ & & $(0.319)$ & & $(0.176)$ & \\
\hline \multirow[t]{2}{*}{$\ln H_{i t}$} & -1.229 & $* * *$ & -2.426 & $* * *$ & -1.350 & $* * *$ & -1.932 & $* *$ & -2.006 & $* * *$ & -1.735 & $* * *$ \\
\hline & $(0.297)$ & & $(0.536)$ & & $(0.387)$ & & $(0.843)$ & & $(0.771)$ & & $(0.374)$ & \\
\hline \multirow[t]{2}{*}{$\ln P O P_{i t} / A R E A_{i}$} & 0.001 & & 0.032 & & -0.020 & & -0.109 & $* *$ & -0.100 & $* *$ & 0.036 & $*$ \\
\hline & $(0.016)$ & & $(0.027)$ & & $(0.020)$ & & $(0.046)$ & & $(0.042)$ & & $(0.019)$ & \\
\hline \multirow[t]{2}{*}{$\ln G D P_{i t} / P O P_{i t}$} & -2.877 & $* * *$ & -3.226 & $* * *$ & -3.081 & $* * *$ & -3.554 & $* * *$ & -3.558 & $* * *$ & -2.576 & $* * *$ \\
\hline & $(0.095)$ & & $(0.155)$ & & $(0.116)$ & & $(0.218)$ & & $(0.201)$ & & $(0.120)$ & \\
\hline \multirow[t]{2}{*}{$\ln I N S P_{i t-1}$} & -0.080 & $* * *$ & -0.049 & & -0.096 & $* *$ & -0.191 & $* *$ & -0.181 & $* *$ & -0.100 & $* * *$ \\
\hline & $(0.025)$ & & $(0.049)$ & & \begin{tabular}{|l|}
$(0.039)$ \\
\end{tabular} & & $(0.078)$ & & $(0.071)$ & & $(0.034)$ & \\
\hline \multirow[t]{2}{*}{$\ln V I O L_{i t-1}$} & -0.057 & $* * *$ & -0.016 & & -0.056 & $* *$ & -0.045 & & -0.020 & & -0.052 & $* *$ \\
\hline & \begin{tabular}{|l|}
$(0.017)$ \\
\end{tabular} & & $(0.031)$ & & \begin{tabular}{|l|}
$(0.024)$ \\
\end{tabular} & & $(0.049)$ & & $(0.045)$ & & $(0.021)$ & \\
\hline \multirow[t]{2}{*}{$\ln P O L L_{i t-1}$} & 0.474 & $* * *$ & 0.895 & $* * *$ & 0.766 & $* * *$ & 0.820 & $* * *$ & 0.805 & $* * *$ & 0.807 & $* * *$ \\
\hline & \begin{tabular}{|l|}
$(0.085)$ \\
\end{tabular} & & $(0.036)$ & & $(0.043)$ & & $(0.044)$ & & $(0.045)$ & & $(0.051)$ & \\
\hline \multirow[t]{2}{*}{ Central } & -0.266 & $* * *$ & -0.268 & $* * *$ & -0.210 & $* * *$ & -0.582 & *** & -0.556 & $* * *$ & -0.207 & $* * *$ \\
\hline & $(0.061)$ & & $(0.095)$ & & $(0.069)$ & & $(0.143)$ & & $(0.131)$ & & $(0.077)$ & \\
\hline \multirow[t]{2}{*}{ Southeast } & -0.330 & $* * *$ & -0.314 & $* * *$ & -0.301 & $* * *$ & -0.508 & $* * *$ & \begin{tabular}{|c|}
-0.488 \\
\end{tabular} & $* * *$ & -0.337 & $* * *$ \\
\hline & $(0.045)$ & & $(0.068)$ & & $(0.052)$ & & $(0.094)$ & & $(0.087)$ & & $(0.055)$ & \\
\hline \multirow[t]{2}{*}{ Southwest } & -0.575 & $* * *$ & -0.565 & $* * *$ & -0.506 & $* * *$ & -0.864 & $* * *$ & -0.833 & $* * *$ & -0.468 & $* * *$ \\
\hline & $(0.064)$ & & $(0.098)$ & & $(0.072)$ & & $(0.145)$ & & $(0.131)$ & & $(0.073)$ & \\
\hline \multirow[t]{2}{*}{ Seoul } & 1.237 & *** & 0.834 & $* * *$ & 0.892 & $* * *$ & 0.713 & $* * *$ & 0.718 & $* * *$ & 1.127 & $* * *$ \\
\hline & $(0.098)$ & & $(0.201)$ & & $(0.127)$ & & $(0.253)$ & & $(0.232)$ & & $(0.137)$ & \\
\hline \multirow[t]{2}{*}{ Јејu } & 1.716 & *** & 1.847 & $* * *$ & 1.830 & $* * *$ & 1.441 & $* * *$ & 1.496 & $* * *$ & 1.623 & $* * *$ \\
\hline & $(0.064)$ & & $(0.097)$ & & $(0.074)$ & & $(0.139)$ & & $(0.126)$ & & $(0.076)$ & \\
\hline \multirow[t]{2}{*}{ Constant } & 35.511 & $* * *$ & 39.665 & $* * *$ & 36.645 & $* * *$ & 40.681 & $* * *$ & 40.641 & $* * *$ & 32.838 & $* * *$ \\
\hline & (1.182) & & $(2.018)$ & & $(1.527)$ & & $(3.162)$ & & $(2.899)$ & & $(1.574)$ & \\
\hline $\mathrm{R}^{2}$ adjusted & 0.966 & & 0.956 & & 0.952 & & 0.928 & & 0.924 & & 0.850 & \\
\hline Observations & 192 & & 192 & & 192 & & 192 & & 192 & & 192 & \\
\hline \multicolumn{13}{|c|}{$\begin{array}{l}\text { a Significance codes: } * \mathrm{p}<0.10, * * \mathrm{p}<0.05, * * * \mathrm{p}<0.01 \\
\mathrm{~b} \text { The standard errors are displayed in parentheses below the respective coefficient estimates. } \\
{ }^{\mathrm{c}} \text { The regressions are estimated with time fixed effects. }\end{array}$} \\
\hline
\end{tabular}

Besides the direct influence, FDI inflows may entail a reduction of the air pollution intensity by increasing per capita income GDP/POP and, hence, the demand for environmental quality. In terms of absolute values per capita income is estimated to be the most important driver of the air pollution intensity. The respective negative and significant coefficients take values between -2.58 and -3.56 . Further important factors that help to reduce the air pollution intensities are in descending order human capital $H$, government expenditures $G O V$, and research and development expenditures $R \& D$. Interestingly these three variables correspond 
to several deployed policy instruments that are part of the first national Five-Year Plan for Green Growth. For instance, educational campaigns, public infrastructure investments in smart grids on Jeju Island, and research and development in energy and low-carbon technologies are targeted to drive the transition to a green growth economy (Mathews 2012). Therefore, the empirical results generally support the focus of implemented policy instruments. The same holds true with regards to regulation as a policy instrument. As can be seen from the coefficients of both air emissions policy enforcement variables $I N S P_{t-1}$ and $V I O L_{t-1}$, an increase in environmental policy stringency, all other things being equal, in most cases entails a significant reduction in air pollution intensities. In particular the number of inspections of air pollution emitting facilities $I N S P_{t-1}$ exhibit significantly negative coefficient estimates ranging between -0.08 and -0.19 for five out of six air pollutants.

On the contrary, a higher capital intensity and technological path dependence are associated with higher air pollution intensities. For both the capital-labor ratio $K / L$ and lagged air pollution emissions $P O L L_{t-1}$ positive and highly significant coefficients are estimated, which is as expected and consistent to earlier research (Cole and Elliott 2003). Lastly, after controlling for Seoul and Jeju fixed-effects, significant differences can be observed across the regions with regards to their air pollution intensities. Ceteris paribus, particularly high intensities can be found in the Seoul metropolitan region for all air pollutants. While this verifies the results of the descriptive analysis of the OECD (2010), the regional variations may be partly an indication for different installed technological bases impacting the local effectiveness of newly installed technologies in reducing air pollution.

\section{VI.IV Estimation of Capital Accumulation Effect}

Apart from the direct scale, composition, and technique effects, FDI inflows can influence the three channels indirectly by changing the physical capital stock $K$. Table- 4 details the regression output of domestic capital accumulation. The partly significant coefficients of FDI inflows on the capital stock are rather small and range between 0.01 and 0.03 . In other words, the capital stock will increase by 0.01 to 0.03 percent if FDI inflows rise by 1 percent. The indirect effects on air pollution through capital accumulation can then be determined by multiplying these coefficient estimates with the respective coefficient of the capital stock in one of the three equations- 2 to 4 . For instance, the scale effect is further increased by $\hat{\delta}_{1} \hat{\alpha}_{2}$. Numerically, for $\mathrm{CO}$, this implies a rise of the impact of FDI on economic growth by $0.01 \times 0.96=0.01$ once capital accumulation is taken into account.

Table-4: Regression Results of Capital Accumulation Effect

\begin{tabular}{|c|c|c|c|c|c|c|c|c|c|c|c|c|}
\hline \multirow[b]{3}{*}{$\ln F D I_{i t}$} & \multicolumn{12}{|c|}{$\ln K_{i t}$} \\
\hline & \multicolumn{2}{|c|}{$\mathrm{CO}_{\text {it }}$} & \multicolumn{2}{|c|}{$S O_{X \text { it }}$} & \multicolumn{2}{|c|}{$N O_{X i t}$} & \multicolumn{2}{|c|}{$T S P_{i t}$} & \multicolumn{2}{|c|}{$P M_{10}$ it } & \multicolumn{2}{|c|}{$V O C_{i t}$} \\
\hline & 0.007 & $*$ & 0.009 & & 0.030 & $* * *$ & 0.010 & & 0.010 & & 0.030 & $* * *$ \\
\hline & $(0.004)$ & & $(0.006)$ & & $(0.006)$ & & $(0.006)$ & & $(0.006)$ & & $(0.006)$ & \\
\hline \multirow{2}{*}{$\ln G D P_{i t-1}$} & 0.480 & $* * *$ & 0.480 & $* * *$ & 0.481 & $* * *$ & 0.489 & $* * *$ & 0.490 & $* * *$ & 0.473 & $* * *$ \\
\hline & $(0.069)$ & & $(0.069)$ & & $(0.074)$ & & $(0.069)$ & & $(0.069)$ & & $(0.074)$ & \\
\hline \multirow[t]{2}{*}{$\ln G D P_{i t-2}$} & 0.047 & & 0.058 & & 0.066 & & 0.055 & & 0.056 & & 0.074 & \\
\hline & $(0.071)$ & & $(0.072)$ & & $(0.077)$ & & $(0.073)$ & & $(0.073)$ & & $(0.077)$ & \\
\hline \multirow[t]{2}{*}{ Constant } & 3.555 & **** & 3.313 & **** & 2.975 & *** & 3.187 & *** & 3.160 & $* * *$ & 2.969 & $* * *$ \\
\hline & $(0.568)$ & & $(0.617)$ & & $(0.639)$ & & $(0.620)$ & & $(0.619)$ & & $(0.629)$ & \\
\hline $\mathrm{R}^{2}$ adjusted & 0.998 & & 0.998 & & 0.996 & & 0.998 & & 0.998 & & 0.996 & \\
\hline Observations & 192 & & 192 & & 192 & & 192 & & 192 & & 192 & \\
\hline $\begin{array}{l}\text { a Significance } \\
\text { b The standarc } \\
{ }^{c} \text { The regressi }\end{array}$ & $\begin{array}{l}\text { les: } * \mathrm{p}< \\
\text { ors are c } \\
\text { are estin }\end{array}$ & displ & $\begin{array}{l}* * \mathrm{p}<0 \\
\text { d in pa } \\
\text { ith time }\end{array}$ & $\begin{array}{l}.01 \\
\text { rentl }\end{array}$ & . & 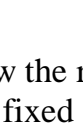 & fects & . & cient & 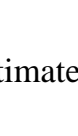 & & \\
\hline
\end{tabular}




\section{VI.V Estimation of Determinants of FDI Inflows}

The regression output of the determinants of FDI inflows are shown in Table-5. Not surprisingly, a significant self-accumulation effect of FDI is estimated. Thereby, a 1 percent rise of foreign investments in the previous year $F D I_{t-1}$ entails a 0.11 percent increase in FDI inflows. This may be explained by motives such as follow-up investments, economic networks, positive experiences of other foreign investors, and the reputation of local regulators. Apart from that, foreign investments are subject to a developed infrastructure $R O A D$ and are attracted by higher wages WAGE. Concerning the latter relationship higher wages may be an indication that FDI is invested in sectors where a higher quality of labor is demanded. This may also be a reason why regional differences in the closely related variable human capital $H$ are estimated to be insignificant. Foreign companies investing in Korea seem to generally expect that labor is highly educated, i.e. slight regional differences in education attainment are not as relevant as other locational factors.

Table-5: Regression Results of Determinants of FDI Inflows

\begin{tabular}{|c|c|c|c|c|c|c|c|c|c|c|c|c|}
\hline \multirow[b]{3}{*}{$\ln F D I_{i t-1}$} & \multicolumn{12}{|c|}{$\ln F D I_{i t}$} \\
\hline & \multicolumn{2}{|l|}{$C O_{i t}$} & \multicolumn{2}{|c|}{$S O_{X i t}$} & \multicolumn{2}{|c|}{$N O_{X i t}$} & \multicolumn{2}{|l|}{$T S P_{i t}$} & \multicolumn{2}{|c|}{$P M_{10 ~ i t}$} & \multicolumn{2}{|c|}{$V O C_{i t}$} \\
\hline & 0.113 & $*$ & 0.106 & $* *$ & 0.110 & $* *$ & 0.110 & $* *$ & 0.109 & $* *$ & 0.101 & $* *$ \\
\hline & $(0.063)$ & & $(0.048)$ & & $(0.045)$ & & $(0.047)$ & & $(0.047)$ & & $(0.050)$ & \\
\hline \multirow[t]{2}{*}{$\ln \mathrm{W} A G E_{i t}$} & 3.864 & $* * *$ & 3.773 & *** & 3.407 & $* * *$ & 3.740 & $* * *$ & 3.743 & *** & 1.846 & $* *$ \\
\hline & $(1.001)$ & & $(0.881)$ & & $(0.873)$ & & $(0.870)$ & & $(0.870)$ & & $(0.938)$ & \\
\hline \multirow[t]{2}{*}{$\ln H_{i t}$} & -2.152 & & -2.183 & & -1.944 & & -2.153 & & -2.116 & & -2.715 & \\
\hline & $(2.325)$ & & $(2.266)$ & & $(2.230)$ & & $(2.260)$ & & $(2.259)$ & & $(2.241)$ & \\
\hline \multirow[t]{2}{*}{$\ln R O A D_{i t}$} & 1.053 & $* * *$ & 0.806 & $* * *$ & 0.924 & $* * *$ & 0.703 & $* *$ & 0.709 & $* *$ & 1.606 & $* * *$ \\
\hline & $(0.323)$ & & $(0.294)$ & & $(0.297)$ & & $(0.283)$ & & $(0.283)$ & & $(0.313)$ & \\
\hline \multirow[t]{2}{*}{$\ln I N S P_{i t-1}$} & 0.954 & $* * *$ & 0.932 & $* * *$ & 0.849 & $* * *$ & 0.970 & $* * *$ & 0.972 & $* * *$ & 0.610 & $* * *$ \\
\hline & $(0.177)$ & & $(0.154)$ & & $(0.154)$ & & $(0.147)$ & & $(0.147)$ & & $(0.165)$ & \\
\hline \multirow[t]{2}{*}{$\ln V I O L_{i t-1}$} & 0.455 & $* *$ & 0.322 & $*$ & 0.281 & $*$ & 0.364 & $* *$ & 0.358 & $* *$ & 0.219 & \\
\hline & $(0.214)$ & & $(0.164)$ & & $(0.157)$ & & $(0.161)$ & & $(0.161)$ & & $(0.172)$ & \\
\hline \multirow[t]{2}{*}{ Central } & 0.290 & & -0.059 & & -0.110 & & -0.050 & & -0.047 & & -0.050 & \\
\hline & $(0.464)$ & & $(0.449)$ & & $(0.448)$ & & $(0.448)$ & & $(0.448)$ & & $(0.453)$ & \\
\hline \multirow[t]{2}{*}{ Southeast } & -0.642 & $*$ & -0.866 & $* *$ & -0.875 & $* *$ & -0.863 & $* *$ & -0.859 & $* *$ & -0.839 & $* *$ \\
\hline & $(0.374)$ & & $(0.367)$ & & $(0.365)$ & & $(0.366)$ & & $(0.366)$ & & $(0.368)$ & \\
\hline \multirow[t]{2}{*}{ Southwest } & -0.396 & & -0.826 & & -0.904 & $*$ & -0.811 & & -0.806 & & -0.913 & $*$ \\
\hline & $(0.540)$ & & $(0.519)$ & & $(0.518)$ & & $(0.517)$ & & $(0.517)$ & & $(0.526)$ & \\
\hline \multirow[t]{2}{*}{ City } & 1.474 & $* * *$ & 1.218 & *** & 1.262 & $* * *$ & 1.119 & $* *$ & 1.125 & $* *$ & 1.973 & $* * *$ \\
\hline & $(0.484)$ & & $(0.458)$ & & $(0.457)$ & & $(0.452)$ & & $(0.453)$ & & $(0.470)$ & \\
\hline \multirow[t]{2}{*}{ Constant } & -70.012 & $* * *$ & -66.259 & **** & -61.201 & $* * *$ & -65.065 & $* * *$ & -65.293 & $* * *$ & -37.469 & $* *$ \\
\hline & $(19.131)$ & & $(16.832)$ & & $(16.602)$ & & $(16.663)$ & & $(16.659)$ & & (17.700) & \\
\hline $\mathrm{R}^{2}$ adjusted & 0.617 & & 0.613 & & 0.618 & & 0.608 & & 0.608 & & 0.630 & \\
\hline Observations & 192 & & 192 & & 192 & & 192 & & 192 & & 192 & \\
\hline $\begin{array}{l}\text { a Significance } \\
\text { b The standarc } \\
{ }^{c} \text { The regressi }\end{array}$ & $\begin{array}{l}\text { es: }{ }^{*} \mathrm{p} \\
\text { rs are }\end{array}$ & lispla & $\begin{array}{l}\mathrm{p}<0.0 \\
\text { in par }\end{array}$ & . & $\begin{array}{l}<0.01 \\
\text { below }\end{array}$ & 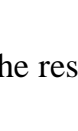 & . & 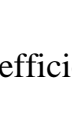 &. & & & \\
\hline
\end{tabular}

In order to detail the underlying nature of foreign investments, the coefficients of the two air pollution policy variables $I N S P_{t-1}$ and $V I O L_{t-1}$ are inspected. Given that the estimates are all positive, an increase in environmental policy stringency is associated with a rise in FDI inflows. Hence, in the case of FDI inflows into Korea stricter policy enforcement does not discourage FDI inflows. Foreign investors seem to be confident to meet the set regulations and the underlying nature of FDI inflows is seemingly rather green. Lastly, apart from 
regional differences in particular in the form of relatively fewer FDI inflows into the southeastern region, foreign firms invest more heavily in urban areas.

\section{VI.VI Estimation of Combined Effects of FDI Inflows on Air Pollution}

The total effect of FDI inflows on air emissions consists of direct and indirect effects. To thoroughly consider these impacts, the regression results from Tables-1 to 5 need to be combined. For that reason, the system of equations is simultaneously solved. Afterwards the first partial derivatives of each variable in the identity-1 are determined with respect to FDI inflows. As a result the combined environmental impacts of FDI, consisting of the scale, composition, and technique effect, are obtained: ${ }^{15}$

Total effect:

$$
\begin{aligned}
\frac{\partial \ln P O L L_{i t}}{\partial \ln F D I_{i t}}= & \hat{\beta}_{1}+\hat{\gamma}_{3}+\hat{\delta}_{1}\left(\hat{\beta}_{3}+\hat{\gamma}_{4}\right) \\
& +\left(1+\hat{\beta}_{4}+\hat{\gamma}_{7}\right) \frac{\hat{\alpha}_{1}+\hat{\alpha}_{2} \hat{\delta}_{1}+\hat{\alpha}_{5}\left(\hat{\beta}_{1}+\hat{\beta}_{3} \hat{\delta}_{1}+\hat{\gamma}_{3}+\hat{\gamma}_{4} \hat{\delta}_{1}\right)}{1-\hat{\alpha}_{5}\left(1+\hat{\beta}_{4}+\hat{\gamma}_{7}\right)}
\end{aligned}
$$

Scale effect:

$$
\frac{\partial \ln G D P_{i t}}{\partial \ln F D I_{i t}}=\frac{\hat{\alpha}_{1}+\hat{\alpha}_{2} \hat{\delta}_{1}+\hat{\alpha}_{5}\left(\hat{\beta}_{1}+\hat{\beta}_{3} \hat{\delta}_{1}+\hat{\gamma}_{3}+\hat{\gamma}_{4} \hat{\delta}_{1}\right)}{1-\hat{\alpha}_{5}\left(1+\hat{\beta}_{4}+\hat{\gamma}_{7}\right)}
$$

Composition effect: $\quad \frac{\partial \ln C O M P_{i t}}{\partial \ln F D I_{i t}}=\hat{\beta}_{1}+\hat{\beta}_{3} \hat{\delta}_{1}+\hat{\beta}_{4} \frac{\hat{\alpha}_{1}+\hat{\alpha}_{2} \hat{\delta}_{1}+\hat{\alpha}_{5}\left(\hat{\beta}_{1}+\hat{\beta}_{3} \hat{\delta}_{1}+\hat{\gamma}_{3}+\hat{\gamma}_{4} \hat{\delta}_{1}\right)}{1-\hat{\alpha}_{5}\left(1+\hat{\beta}_{4}+\hat{\gamma}_{7}\right)}$

Technique effect: $\quad \frac{\partial \ln T E C H_{i t}}{\partial \ln F D I_{i t}}=\hat{\gamma}_{3}+\hat{\gamma}_{4} \hat{\delta}_{1}+\hat{\gamma}_{7} \frac{\hat{\alpha}_{1}+\hat{\alpha}_{2} \hat{\delta}_{1}+\hat{\alpha}_{5}\left(\hat{\beta}_{1}+\hat{\beta}_{3} \hat{\delta}_{1}+\hat{\gamma}_{3}+\hat{\gamma}_{4} \hat{\delta}_{1}\right)}{1-\hat{\alpha}_{5}\left(1+\hat{\beta}_{4}+\hat{\gamma}_{7}\right)}$

The total effect $\partial \ln P O L L / \partial \ln F D I$ can be decomposed as follows: First, FDI inflows directly impact air pollution through the scale, composition, and technique effect measured via the coefficients $\hat{\alpha}_{1}, \hat{\beta}_{1}$, and $\hat{\gamma}_{3}$ respectively. While the direct scale and composition effect are estimated to be positive, the direct technique effect is mainly negative. Second, the framework considers two indirect effects of FDI. On the one hand, FDI slightly increases the domestic capital stock via $\hat{\delta}_{1}$. Given that the capital stock in turn affects economic growth, the industrial composition, and pollution intensity through the coefficients $\hat{\alpha}_{2}, \hat{\beta}_{3}$, and $\hat{\gamma}_{4}$, the indirect effect of FDI through capital accumulation is measured as $\hat{\delta}_{1}\left(\hat{\alpha}_{2}+\hat{\beta}_{3}+\hat{\gamma}_{4}\right)$. On the other hand, by increasing the gross regional product FDI inflows are indirectly affecting the composition and technique effect in the form of $\hat{\beta}_{4}$ and $\hat{\gamma}_{7}$. In the case of Korea, the induced economic growth increases air emissions as it is associated with a rise in the share of industrial value added in the total economy. At the same time, the rising per capita income strongly entails a higher demand for environmental quality and a decrease in the pollution intensity through the indirect technique effect. Lastly, air pollution is estimated to have a positive feedback effect on economic growth via $\hat{\alpha}_{5}$. As the increased gross regional product in turn influences the composition and technique effect through $\hat{\beta}_{4}$ and $\hat{\gamma}_{7}$, the overall feedback effect of air pollution is given by $\hat{\alpha}_{5}\left(1+\hat{\beta}_{4}+\hat{\gamma}_{7}\right)$.

\footnotetext{
${ }^{15}$ Please see Appendix-D for a detailed mathematical derivation of the combined environmental effects of FDI.
} 
By using the estimated coefficients from Tables-1 to 5, the combined environmental effects of FDI can then be determined. In order to assess their statistical significance standard errors are approximated with the help of the Delta method. The estimated results are shown in Table-6 and further decomposed into the direct and indirect effects in Table-7. The scale effect of FDI inflows is estimated to be significantly positive across all six air pollutants. Thereby, the effect lies between 0.09 and 0.18 , inferring that a 1 percent increase in FDI inflows is associated with 0.09 to 0.18 percent growth of the gross regional product. This corresponds to similar findings on the FDI-growth literature on Korea of Kim and Seo (2003), Carkovic and Levine (2005), and more recently Koojaroenprasit (2012), who also reveal some evidence of a positive impact of FDI on economic growth. However, while the previous studies analyzed the direct impact of FDI using data on the national level, this paper takes regional differences as well as indirect scale effects into account. Namely, the indirect impacts of FDI on economic growth through the increased capital accumulation and the positive feedback effect of air pollution emissions are considered. Even though the estimated indirect effect, ranging between 0.01 and 0.04 , is significantly smaller than the direct one, an omission of the indirect channels may result in an underestimation of the scale effect. All in all, the estimated positive scale effect implies for Korea that the entry of foreign firms enhances economic growth, which in turn raises total air pollution.

Table-6: Estimation Results of Combined Effects of FDI Inflows on Air Pollution

\begin{tabular}{|c|c|c|c|c|c|c|}
\hline & $\mathrm{CO}_{i t}$ & $S O_{X i t}$ & $N O_{X i t}$ & $T S P_{i t}$ & $P M_{10}$ it & $V O C_{i t}$ \\
\hline \multirow{2}{*}{$\begin{array}{l}\text { Total effect } \\
\partial P O L L_{i t} / \partial F D I_{i t}\end{array}$} & 0.024 & -0.013 & $0.068 * * *$ & -0.066 & -0.071 & -0.015 \\
\hline & $(0.020)$ & $(0.033)$ & $(0.024)$ & $(0.052)$ & $(0.047)$ & $(0.027)$ \\
\hline \multirow{2}{*}{$\begin{array}{l}\text { Scale effect } \\
\partial G D P_{i t} / \partial F D I_{i t}\end{array}$} & $0.087 * * *$ & 0.176 *** & $0.184 * * *$ & $0.183 * * *$ & $0.183 * * *$ & $\left.0.115\right|^{* * *}$ \\
\hline & $(0.015)$ & $(0.016)$ & $(0.015)$ & $(0.016)$ & $(0.016)$ & $(0.014)$ \\
\hline \multirow{2}{*}{$\begin{array}{l}\text { Composition effect } \\
\partial C O M P_{i t} / \partial F D I_{i t}\end{array}$} & $0.196 * * *$ & $0.377 * * *$ & $0.358 * * *$ & $0.389 * * *$ & 0.387 *** & 0.221 *** \\
\hline & $(0.034)$ & $(0.035)$ & $(0.033)$ & $(0.036)$ & $(0.036)$ & $(0.031)$ \\
\hline \multirow{2}{*}{$\begin{array}{l}\text { Technique effect } \\
\partial T E C H_{i t} / \partial F D I_{i t}\end{array}$} & -0.259 *** & -0.566 *** & $-0.474 * * *$ & $-0.638 * * *$ & -0.641 **** & $-0.350 * * *$ \\
\hline & $(0.040)$ & $(0.059)$ & $(0.047)$ & $(0.074)$ & $(0.071)$ & $(0.038)$ \\
\hline
\end{tabular}

Table-7: Decomposition of Environmental Effects of FDI Inflows

\begin{tabular}{|l|c|r|r|r|r|r|}
\hline & $\boldsymbol{C O}_{\boldsymbol{i t}}$ & \multicolumn{1}{c|}{$\boldsymbol{S O}_{\boldsymbol{X} \text { it }}$} & \multicolumn{1}{c|}{$\boldsymbol{N O}_{\boldsymbol{X} \text { it }}$} & $\boldsymbol{T S P}_{\boldsymbol{i t}}$ & $\boldsymbol{P M}_{\mathbf{1 0} \text { it }}$ & $\boldsymbol{V O C}_{\boldsymbol{i t}}$ \\
\hline Scale effect & 0.087 & 0.176 & 0.184 & 0.183 & 0.183 & 0.115 \\
\hline Direct scale effect & 0.072 & 0.168 & 0.146 & 0.175 & 0.174 & 0.091 \\
\hline Indirect scale effect & 0.015 & 0.008 & 0.037 & 0.008 & 0.008 & 0.024 \\
\hline Composition effect & 0.196 & 0.377 & 0.358 & 0.389 & 0.387 & 0.221 \\
\hline Direct composition effect & 0.028 & 0.034 & 0.049 & 0.033 & 0.033 & 0.050 \\
\hline Indirect composition effect & 0.168 & 0.344 & 0.308 & 0.356 & 0.354 & 0.171 \\
\hline Technique effect & -0.259 & -0.566 & -0.474 & -0.638 & -0.641 & -0.350 \\
\hline Direct technique effect & -0.023 & -0.024 & 0.012 & -0.022 & -0.027 & -0.113 \\
\hline Indirect technique effect & -0.236 & -0.542 & -0.486 & -0.616 & -0.614 & -0.237 \\
\hline
\end{tabular}

The deteriorating effect on total air pollution is further increased by the positive composition effect, which ranges between 0.20 and 0.39 . Hence, increasing the invested foreign capital adds positively to the share of industrial value added relative to the total economy. Given that industrial sectors are relatively pollution-intensive compared to service sectors, total air emissions rise. Thereby, the direct composition effect contributes less than the indirect one to the overall impact. The rather small but significant direct effect may be explained by the 
circumstance that large shares of FDI are invested in both manufacturing and service sectors and that FDI seems to be relatively more efficient with regards to the generation of value added in the secondary sector. The positive indirect composition effect can be particularly attributed to the feedback of the scale effect on the industrial composition. The indirect impact via domestic capital accumulation is rather low owing to the partly insignificant coefficient $\hat{\delta}_{1}$.

The increase in total air emissions via the scale and composition effect is then mainly leveled by the negative technique effect. The estimated technique effects denote that air pollution intensities drop between 0.26 and 0.64 percent if FDI inflows rise by 1 percent. To some extent foreign firms seem to adopt cleaner technologies and production processes than the average capital base. The results partly contradict the finding of Aden et al. (1999), who detect that in terms of pollution abatement foreign firms perform worse than domestic Korean firms. If the absolute values are considered the estimated technique effect is the strongest of the three environmental effects of FDI across all analyzed air pollutants. Especially the indirect technique effect significantly contributes to control of air pollution. Thereby, the positive indirect effect via domestic capital accumulation, which results in a higher pollution intensity, is outweighed by the increased demand for environmental quality via the indirect effect of FDI on per capita income. In other words, through the creation of high-paid jobs, which are expected to coincide with high-skilled labor employment necessary for the development of new technologies, FDI is likely to contribute to an innovative creative economy in Korea and increases the demand for an environmental clean-up.

The three environmental effects add up to the total effect, which is apart from $\mathrm{NO}_{\mathrm{x}}$ not significantly different from zero. In other words, an increase of FDI inflows into Korea in most cases does not change total air pollution emissions. This finding is believed to rather weigh in favor of FDI inflows, given that foreign investments are estimated to boost economic growth and that Korea has already developed into a highly advanced economy during the last decades. The slight deteriorating environmental impact of FDI inflows in the case of $\mathrm{NO}_{\mathrm{x}}$ has mainly two reasons. On the one hand, the induced effect of FDI on economic growth is the largest for the six air pollutants. On the other hand, the impact of FDI inflows on domestic capital accumulation is also the strongest, which in turn mitigates the negative technique effect.

\section{Conclusion and Policy Implications}

This paper examines whether FDI has a positive or negative impact on province-level air pollution in Korea to make inferences on the role that FDI may inherit in the long term national green growth strategy. Specifically, the environmental impacts of FDI are decomposed into a scale, composition, and technique effect and estimated with the help of a system of simultaneous equations. To improve the accuracy of the estimates of three effects both the direct as well as indirect impacts of FDI on pollution emissions and a feedback effect of pollution emissions on FDI are included in the empirical analysis. Potential problems of endogeneity are controlled for by applying the 3SLS estimator. Thereby, the analysis utilizes detailed panel data on six air pollutants in 16 Korean provinces and self-governing cities for the period of 2000-2011.

The study supplements the previous research on the FDI-environment nexus by providing new regional evidence for a newly developed country that has rarely been explored. The major results are as follows: Overall, FDI mainly has neither a positive nor a negative impact on the total emissions level in Korea. Out of the six air pollutants only the emissions level of $\mathrm{NO}_{\mathrm{x}}$ is increased owing to FDI inflows. The analysis of the three main channels of FDI then 
allows an assessment of the extent that FDI may contribute to the green growth path. The scale and composition effects are estimated to be positive and highly significant. In other words, FDI inflows foster economic growth and development of industrial sectors in Korea. In this regard the results both support and complement the findings of the existing literature on the FDI-growth relationship on Korea relying for national level data. The increase in the total emissions level through scale and composition effects is for five out of six of the air pollutants offset by the technique effect. Hence, FDI inflows also entail a significant reduction in air pollution intensities. This includes to a limited extent that foreign investors also seem to install cleaner technologies than the average capital base. Such a result is at least partly contrary to the earlier findings of Aden et al. (1999), who detect during a time period when total air emissions rose that firms with some level of foreign ownership spent less on pollution abatement than their Korean counterparts. Furthermore, the distribution of the three effects into direct and indirect effects shows that both channels are relevant for the development of the total emissions level. For Korea, in particular the indirect technique effect significantly contributes to the control of air pollution. Thus, in order to correctly evaluate the environmental effect of FDI for a technologically advanced economy like Korea, it is also necessary to consider indirect effects induced through capital formation and changes in per capita income. Lastly, the impact of FDI on air emissions may vary considerably among regions. Given the regional differences in economic development, industrial composition, and installed environmental technologies, this finding seems quite intuitive. Nonetheless, when designing appropriate economic and environmental policies regional characteristics should not be disregarded.

In order to regard FDI as a potential tool to achieve Korea's green growth strategy it seems to be important that mainly two criteria are fulfilled. First, FDI needs to facilitate (long run) economic growth. Given the significantly positive scale effects across all estimations the paper clearly shows that this has been the case for the analyzed time period. Second, FDI needs to support the clean-up of sectors by either changing the domestic industrial composition or by reducing industrial emission intensities. While the analysis reveals that FDI increases the share of industrial value added in the total economy, this paper, limited by its regional nature, cannot exhaustively evaluate whether FDI results in a transformation of the domestic industrial composition. In other words, FDI does not induce a deindustrialization, i.e. a shift of the value added from manufacturing to cleaner service sectors, which is perhaps also not intended by this industrial green growth policy. Yet, disaggregated, sector-specific data would be required to provide certain evidence that FDI supports the value creation in innovative, green technology industrial sectors more than in energy-intensive industries. Given that foreign investments are associated with higher wages in Korea the results, nevertheless, provide an indication that FDI is invested in sectors where high skilled labor is demanded - a corresponding precondition to move towards an innovative creative economy. Similarly, FDI inflows tend to be attracted by stricter air pollution controls indicating that the underlying nature of FDI inflows is rather green. This picture is supported by the significant reduction in the pollution intensities induced through the technique effect, the strongest of the three environmental effects. Hence, the paper reveals that FDI inflows concurrently stimulate economic growth and reduce air pollution intensities, while the total level of air pollution mostly remains unchanged. Even though it may be regarded a limitation that FDI enhances the clean-up of sectors predominantly through indirect channels and less directly through the adoption of environmentally friendly technologies, these findings provide sufficient support for the fulfillment of both criteria. Given Korea's high level of development, foreign investments are, therefore, regarded as one potential pillar to achieve the goals of the green growth strategy. From a policy perspective, the findings suggest that Korean officials should encourage FDI inflows through instruments that include region-specific incentives. 
Future research concentrating on regional aspects may further the analysis in mainly three ways. First, given the data availability the study focuses on examining the impact of FDI on local air pollutants. This has the positive implication that the analyzed pollutants not only are a by-product of goods production and subject to regulation, but also have strong local effects. However, the Korean green growth strategy also aims at significantly reducing emissions of global greenhouse gases like $\mathrm{CO}_{2}$. A supplementary analysis of the impact of FDI on greenhouse gas emissions may be valuable to analyze the robustness of this study's findings concerning global pollutants. Second, the same holds true with regards to the announcement of the green growth strategy in 2008. While this paper considers the time period from 2000 to 2011 and analyzes whether FDI may help to achieve the green growth targets in the future, the proclamation of the green growth strategy may have altered the environmental nature of foreign investments in Korea. Hence, if greener FDI inflows are attracted, scale, composition, and technique effects may change respectively leading to an underestimation of total environmental effect. ${ }^{16}$ Finally, the underlying analysis allows for comparing the environmental impact of FDI inflows to the existing average stock of physical capital. A regional comparison of air pollution induced by foreign capital to the one induced by domestically financed capital will further help policymakers to clarify their treatment of FDI relative to domestic investments.

\section{References}

Aden, J., Kyu-Hong, A. and Rock, M.T. (1999). What is driving the pollution abatement expenditure behavior of manufacturing plants in Korea? World Development, 27(7), 12031214.

Albornoz, F., Cole, M.A., Elliott, R.J.R. and Ercolani, M.G. (2009). In Search of Environmental Spillovers. World Economy, 32(1), 136-163.

Althammer, W. and Hille, E. (2016). Measuring climate policy stringency: A shadow price approach. International Tax and Public Finance, 23(4), 607-639.

Antweiler, W., Copeland, B.R. and Taylor, M.S. (2001). Is free trade good for the environment? American Economic Review, 91(4), 877-908.

Bao, Q., Chen, Y. and Song, L. (2011). Foreign direct investment and environmental pollution in China: A simultaneous equations estimation. Environment and Development Economics, 16(1), 71-92.

Barro, R.J. and Lee, J.W. (2013). A new data set of educational attainment in the world, 19502010. Journal of Development Economics, 104(C), 184-198.

Carkovic, M. and Levine, R. (2005). Does foreign direct investment accelerate economic growth? In T. Moran, E.M. Graham and M. Blomström (Eds.), Does foreign direct investment promote development? (pp. 195-220). Washington, DC, USA: Institute for International Economics.

Caselli, F. (1999). Technological Revolutions. American Economic Review, 89(1), 78-102.

Choi, E., Heshmati, A. and Cho, Y. (2011). An empirical study of the relationships between $\mathrm{CO} 2$ emissions, economic growth and openness. Korean Journal of Environmental Policy, 10(4), 3-37.

Chow, P.C.Y. (2012). Trade and industrial development in East Asia: Catching up or falling behind. Cheltenham, UK: Edward Elgar Publishing.

Chung, S. (2014). Environmental regulation and foreign direct investment: Evidence from South Korea. Journal of Development Economics, 108(C), 222-236.

\footnotetext{
${ }^{16}$ Given the data availability only information on three years after the proclamation of the green growth strategy are analyzed. Consequently, the limited degrees of freedom restrict the possibility to both estimate the direct and indirect environmental effects and distinguish the extent of these effects before and after the proclamation of the green growth strategy.
} 
Cole, M.A. and Elliot, R.J.R. (2003). Determining the trade-environment composition effect: The role of capital, labor and environmental regulations. Journal of Environmental Economics and Management, 46(3), 363-383.

Cole, M.A., Elliot, R.J.R. and Zhang, L. (2017). Foreign direct investment and the environment. Annual Review of Environment and Resources, 42(1), 465-487.

Copeland, B.R. and Taylor, M.S. (2003). Trade and the environment: Theory and evidence. Princeton, NJ, USA: Princeton University Press.

Copeland, B.R. and Taylor, M.S. (2004). Trade, growth, and the environment. Journal of Economic Literature, 42(1), 7-71.

Derbyshire, J., Gardiner, B. and Waights, S. (2013). Estimating the capital stock for the NUTS2 regions of the EU27. Applied Economics, 45(9), 1133-1149.

He, J. (2006). Pollution haven hypothesis and environmental impacts of foreign direct investment: The case of industrial emission of sulfur dioxide (SO2) in Chinese provinces. Ecological Economics, 60(1), 228-245.

He, J. (2008). Foreign direct investment and air pollution in China: Evidence from Chinese cities. Région et Développement, 28, 131-150.

Hille, E. (2018). Pollution havens: International empirical evidence using a shadow price measure of climate policy stringency. Empirical Economics, 54(3), 1137-1171.

Hübler, M. (2011). Technology diffusion under contraction and convergence: A CGE analysis of China. Energy Economics, 33(1), 131-142.

Jiang, X., Zhu, K. and Wang, S. (2015). The potential for reducing China's carbon dioxide emissions: Role of foreign-invested enterprises. Global Environmental Change, 35(1), $22-$ 30.

Jones, R.S. and Yoo, B. (2011). Korea's green growth strategy: Mitigating climate change and developing new growth engines. OECD Economics Department Working Papers, No. 798, OECD Publishing.

Kheder, S.B. (2010). French FDI and pollution emissions: An empirical investigation. CERDI Working Paper, November 2010.

Kim, E. and Jeong, Y.H. (2003). Decomposition of regional income inequality in Korea. Review of Regional Studies, 33(3), 313-327.

Kim, D.D. and Seo, J. (2003). Does FDI inflow crowd out domestic investment in Korea? Journal of Economic Studies, 30(3), 605-622.

Kim, S.-Y. and Thurbon, E. (2015). Developmental environmentalism: Explaining South Korea's ambitious pursuit of green growth. Politics and Society, 43(2), 213-240.

Koojaroenprasit, S. (2012). The impact of foreign direct investment on economic growth: A case study of South Korea. International Journal of Business and Social Science, 3(21), 819.

Korean Statistical Information Service (2014). Regional accounts. http://kosis.kr/. Accessed 12 December 2014.

Korean Trade-Investment Promotion Agency (2014). Korean inward FDI distribution by province. Received 12 August 2014.

Liang, F.H. (2006). Does foreign direct investment harm the host country's environment? Evidence from China. Haas School of Business Working Paper, 12 April 2006.

Lau, L.-S., Choong, C.-K. and Eng, Y.-K. (2014). Investigation of the environmental Kuznets curve for carbon emissions in Malaysia: Do foreign direct investment and trade matter? Energy Policy, 68(1), 490-497.

Leonardi, M. (2007). Firm heterogeneity in capital-labour ratios and wage inequality. Economic Journal, 117(518), 375-398.

Mathews, J.A. (2012). Green growth strategies - Korean initiatives. Futures, 44(8), 761-769 
Ministry of Strategy and Finance (2013). The Park Geun-Hye administration's creative economy blueprint, 'Creative economy action plan and measures to establish a creative economic ecosystem'. 05 June 2013.

Mun, B. and Mun, S. (2015). Will foreign direct investment accelerate the economic integration of East Asia? An analysis of the changing trade structure in East Asia due to increasing FDI and economic effects thereof. IIT Working Paper, No. 15-01.

National Institute of Environmental Research (2018). National air pollutant emissions http://airemiss.nier.go.kr. Accessed 10 January 2018.

Neequaye, N.A. and Oladi, R. (2015). Environment, growth, and FDI revisited. International Review of Economics and Finance, 39(1), 47-56.

Nicolas, F., Thomsen, S. and Bang, M. (2013). Lessons from investment policy reform in Korea. OECD Working Papers on International Investment, No. 2013/02, OECD Publishing.

Noland, M. (2007). South Korea's experience with international capital flows. In S. Edwards (Ed.), Capital controls and capital flows in emerging economies: Policies, practices and consequences (pp. 481-528). Chicago, IL, USA: University of Chicago Press.

Omri, A., Nguyen, D.K. and Rault, C. (2014). Causal interactions between CO2 emissions, FDI, and economic growth: Evidence from dynamic simultaneous-equation models. Economic Modelling, 42(1), 382-389.

OECD (2010). Taxation, innovation and the environment. Paris, France: OECD Publishing.

OECD (2017). Environmental Policy Stringency Index and FDI statistics according to Benchmark Definition 3rd Edition (BMD3). http://stats.oecd.org/. Accessed 10 November 2017.

Pazienza, P. (2015). The environmental impact of the FDI inflow in the transport sector of OECD countries and policy implications. International Advances in Economic Research, 21(1), 105-116.

Shahbaz, M., Nasreen, S., Abbas, F. and Anis, O. (2015). Does foreign direct investment impede environmental quality in high-, middle-, and low-income countries? Energy Economics, 51(1), 275-287.

Wang, H. and Jin, Y. (2007). Industrial ownership and environmental performance: Evidence from China. Environmental and Resource Economics, 36(3), 255-273.

World Bank (2016). World development indicators. http://databank.worldbank.org/. Accessed 12 January 2016.

World Input-Output Database (2014). WIOD Socio-Economic Accounts. Released July 2014.

Yang, B., Brosig, S. and Chen, J. (2013). Environmental impact of foreign vs. domestic capital investment in China. Journal of Agricultural Economics, 64(1), 245-271.

Yang, W.-P., Yang, Y. and Yue, J. (2008). The impact of foreign trade and FDI on environmental pollution. China-USA Business Review, 7(12), 1-11.

Zarsky, L. (1999). Havens, halos and spaghetti: Untangling the evidence about foreign direct investment and the environment. OECD Proceedings: Foreign Direct Investment and the Environment, 47-73.

Zellner, A. and Theil, H. (1962). Three-stage least squares: simultaneous estimation of simultaneous equations. Econometrica, 30(1), 54-78. 


\section{Appendix A: Different impact channels of FDI on air pollution emissions}

Figure-3: Overview of the FDI-pollution relationship including the direct effects on the arrows

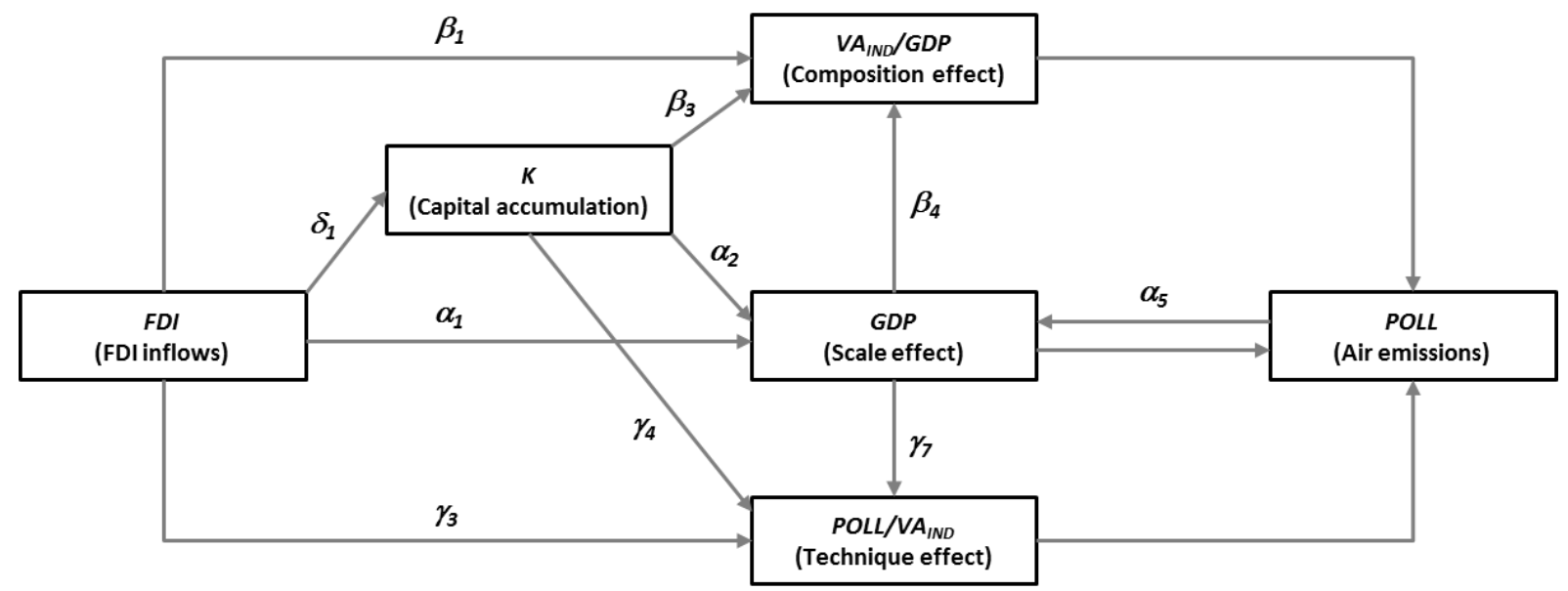

\section{Appendix B: Regional classification}

Figure-4: Allocation of Korean provinces into four regions

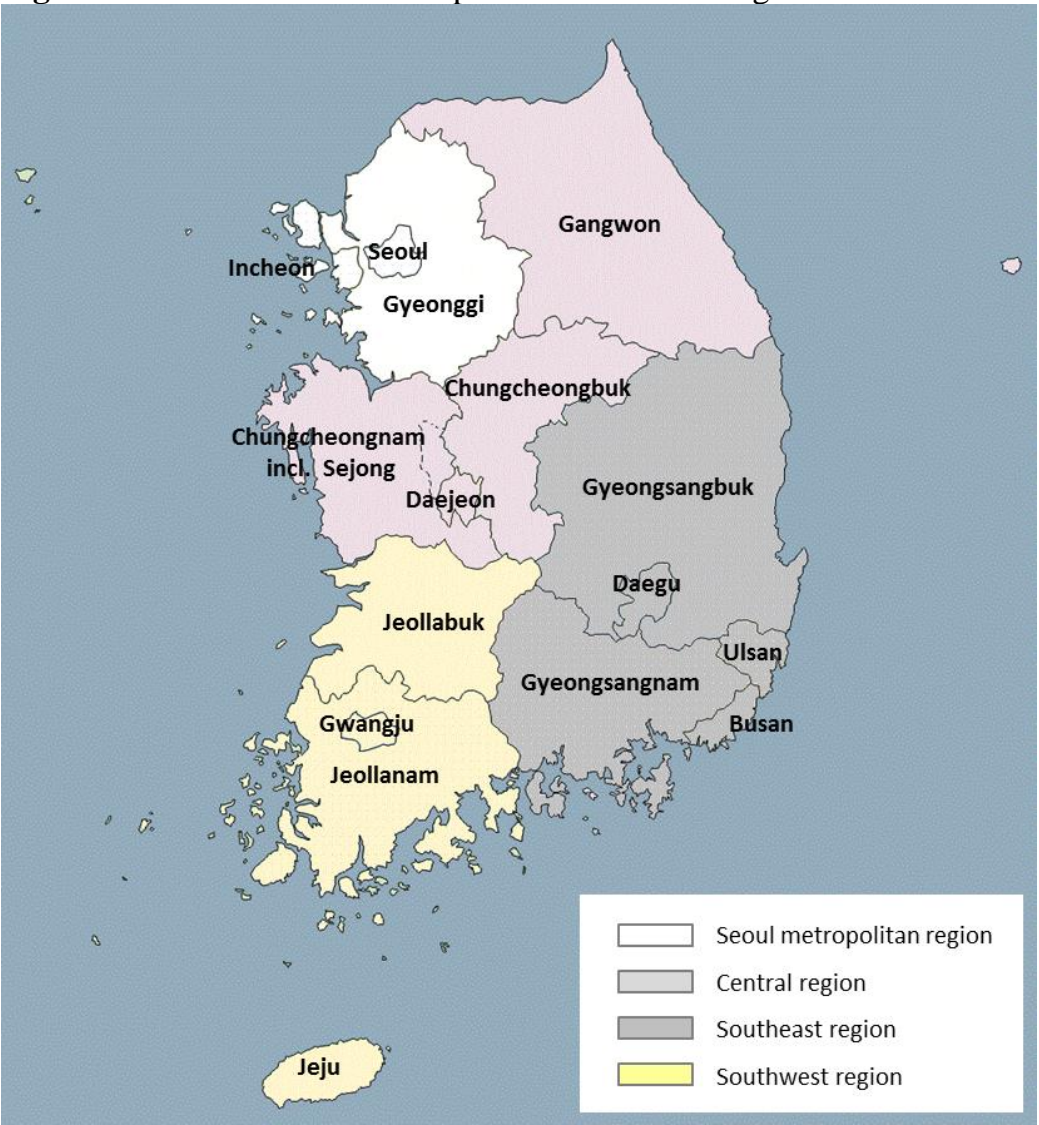




\section{Appendix C: Overview and descriptive statistics of the final variables}

Table-8: Used Variables and their Units of Measurement

\begin{tabular}{|c|c|c|}
\hline Abbreviation & Final variable & Unit of measurement \\
\hline $\mathrm{CO}$ & Total emissions CO & Ton \\
\hline$N O_{X}$ & Total emissions $\mathrm{NO}_{\mathrm{X}}$ & Ton \\
\hline$S O_{X}$ & Total emissions $\mathrm{SO}_{\mathrm{X}}$ & Ton \\
\hline$T S P$ & Total emissions TSP & Ton \\
\hline$P M_{10}$ & Total emissions $\mathrm{PM}_{10}$ & Ton \\
\hline VOC & Total emissions VOC & Ton \\
\hline$P O L L / V A_{I N D}$ & Total emissions per gross industrial value added & Gram per million Won 2005 prices \\
\hline$G D P$ & Gross regional product & Million Won 2005 prices \\
\hline GDP/POP & Per capita gross regional product & Thousand Won 2005 prices \\
\hline$V A_{I N D} / G D P$ & $\begin{array}{l}\text { Share of the gross industrial value added of the } \\
\text { gross regional product }\end{array}$ & Percentage \\
\hline FDI & FDI inflows & Billion Won 2005 prices \\
\hline$K$ & Capital stock & Billion Won 2005 prices \\
\hline$L$ & Total annual working hours of employed people & Thousand working hours \\
\hline$K / L$ & Ratio of physical capital stock to labor & Million Won 2005 prices per working hour \\
\hline$H$ & $\begin{array}{l}\text { Average number of education years of the } \\
\text { economically active population }\end{array}$ & Years per economically active person \\
\hline$W A G E$ & Average annual salary of employees & Won 2005 prices per employed person \\
\hline POP/AREA & Population density & People per square kilometer \\
\hline$R \& D$ & Total R\&D expenditures & Million Won 2005 prices \\
\hline GOV & $\begin{array}{l}\text { Government expenditures on health, welfare, } \\
\text { and the environment }\end{array}$ & Million Won 2005 prices \\
\hline INSP & Inspections of air pollution emitting facilities & Instances \\
\hline VIOL & $\begin{array}{l}\text { Detected violations per inspection of air } \\
\text { pollution emitting facility }\end{array}$ & Percentage \\
\hline$R O A D$ & Length of paved roads & Kilometer \\
\hline
\end{tabular}

${ }^{a}$ Dummy variables are not included in the overview. 
Table-9: Descriptive Statistics

\begin{tabular}{|c|c|c|c|c|}
\hline Variable & AVG & SD & MIN & MAX \\
\hline $\mathrm{CO}$ & 50,129 & 39,472 & 7,566 & 193,907 \\
\hline$N O_{X}$ & 74,241 & 51,108 & 9,568 & 234,958 \\
\hline$S O_{X}$ & 27,434 & 24,955 & 932 & 103,959 \\
\hline$T S P$ & 7,546 & 11,087 & 404 & 79,180 \\
\hline$P M_{10}$ & 5,291 & 6,567 & 370 & 46,125 \\
\hline$V O C$ & 50,067 & 36,947 & 4,919 & 176,946 \\
\hline$C O_{t-1}$ & 50,998 & 40,714 & 7,566 & 193,907 \\
\hline$N O_{X t-1}$ & 74,408 & 51,277 & 9,568 & 234,958 \\
\hline$S O_{X t-1}$ & 27,699 & 24,846 & 1,046 & 103,959 \\
\hline$T S P_{t-1}$ & 6,936 & 9,202 & 404 & 62,162 \\
\hline$P M_{10 t-1}$ & 4,937 & 5,510 & 370 & 36,612 \\
\hline$V O C_{t-1}$ & 48,983 & 36,419 & 4,832 & 176,946 \\
\hline$C O / V A_{I N D}$ & 6,936 & 8,002 & 1,157 & 39,522 \\
\hline$N O_{X} / V A_{I N D}$ & 9,457 & 10,354 & 1,613 & 49,836 \\
\hline$S O_{X} / V A_{I N D}$ & 2,942 & 3,025 & 141 & 14,297 \\
\hline$T S P / V A_{I N D}$ & 976 & 2,361 & 65 & 20,065 \\
\hline$P M_{10} / V A_{I N D}$ & 683 & 1,395 & 60 & 11,688 \\
\hline$V O C / V A_{I N D}$ & 5,397 & 4,623 & 1,480 & 31,891 \\
\hline$G D P$ & $55,951,005$ & $56,681,167$ & $6,447,702$ & $247,003,197$ \\
\hline$G D P_{t-1}$ & $53,515,400$ & $54,250,123$ & $5,888,949$ & $241,052,237$ \\
\hline$G D P_{t-2}$ & $50,976,802$ & $51,848,942$ & $5,576,159$ & $237,593,605$ \\
\hline GDP/POP & 18,800 & 7,167 & 10,266 & 44,788 \\
\hline$V A_{I N D} / G D P$ & $26.2 \%$ & $13.8 \%$ & $2.8 \%$ & $54.3 \%$ \\
\hline$F D I$ & 413 & 892 & 0 & 4,894 \\
\hline$F D I_{t-1}$ & 432 & 1,018 & 0 & 7,831 \\
\hline$K$ & 179,506 & 200,273 & 20,076 & 899,087 \\
\hline$L$ & 3,373 & 3,197 & 618 & 13,404 \\
\hline$K / L$ & 51.1 & 13.6 & 29.0 & 88.2 \\
\hline$H$ & 12.5 & 1.0 & 10.1 & 14.4 \\
\hline$W A G E$ & $26,964,721$ & $6,025,632$ & $16,344,858$ & $46,674,960$ \\
\hline POP/AREA & 2,246 & 3,960 & 87 & 16,695 \\
\hline$R \& D$ & $1,674,349$ & $2,864,027$ & 26,905 & $17,238,259$ \\
\hline$G O V$ & $1,827,008$ & $1,766,896$ & 211,804 & $8,857,493$ \\
\hline$I N S P_{t-1}$ & 2,719 & 2,923 & 158 & 17,955 \\
\hline$V_{I O L} L_{t-1}$ & $5.1 \%$ & $3.6 \%$ & $0.7 \%$ & $27.1 \%$ \\
\hline$R O A D$ & 4,867 & 2,869 & 1,174 & 11,357 \\
\hline
\end{tabular}




\section{Appendix D: Determination of the combined environmental impacts of FDI}

In order to numerically determine the combined environmental effects of FDI, the partial derivatives of each variable in the identity-1 need to be determined with respect to $F D I_{i t}$. The aim is to calculate the total effect $\frac{\partial \ln P O L L_{i t}}{\partial \ln F D I_{i t}}$, the scale effect $\frac{\partial \ln G D P_{i t}}{\partial \ln F D I_{i t}}$, the composition effect $\frac{\partial \ln C O M P_{i t}}{\partial \ln F D I_{i t}}$, and the technique effect $\frac{\partial \ln T E C H_{i t}}{\partial \ln F D I_{i t}}$.

Given that the simultaneous equations model includes several endogenous variables, namely $F D I_{i t}, G D P_{i t}, V A_{I N D} i t, K_{i t}$, and $P O L L_{i t}$, equations-2 to 5 can in the first step be reduced to those variables:

$$
\begin{aligned}
& \ln G D P_{i t}=\hat{\alpha}_{1} \ln F D I_{i t}+\hat{\alpha}_{2} \ln K_{i t}+\hat{\alpha}_{5} \ln P O L L_{i t}+\bullet \\
& \ln C O M P_{i t}=\ln V A_{I N D i t}-\ln G D P_{i t}=\hat{\beta}_{1} \ln F D I_{i t}+\hat{\beta}_{3} \ln K_{i t}+\hat{\beta}_{4} \ln G D P_{i t}+\bullet \\
& \ln T E C H_{i t}=\ln P O L L_{i t}-\ln V A_{I N D i t}=\hat{\gamma}_{3} \ln F D I_{i t}+\hat{\gamma}_{4} \ln K_{i t}+\hat{\gamma}_{7} \ln G D P_{i t}+\bullet \\
& \ln K_{i t}=\hat{\delta}_{1} \ln F D I_{i t}+\bullet
\end{aligned}
$$

Insert (D.4) into (D.1), (D.2), and (D.3):

$$
\begin{aligned}
& \ln G D P_{i t}=\left(\hat{\alpha}_{1}+\hat{\alpha}_{2} \hat{\delta}_{1}\right) \ln F D I_{i t}+\hat{\alpha}_{5} \ln P O L L_{i t}+\bullet \\
& \ln C O M P_{i t}=\ln V A_{I N D i t}-\ln G D P_{i t}=\left(\hat{\beta}_{1}+\hat{\beta}_{3} \hat{\delta}_{1}\right) \ln F D I_{i t}+\hat{\beta}_{4} \ln G D P_{i t}+\bullet \\
& \ln T E C H_{i t}=\ln P O L L_{i t}-\ln V A_{I N D i t}=\left(\hat{\gamma}_{3}+\hat{\gamma}_{4} \hat{\delta}_{1}\right) \ln F D I_{i t}+\hat{\gamma}_{7} \ln G D P_{i t}+\bullet
\end{aligned}
$$

From here on the individual effects can be determined. First, the scale effect is calculated.

Solve both (D.6) and (D.7) for $V A_{I N D}$ it:

$$
\begin{aligned}
& \ln V A_{I N D i t}=\left(\hat{\beta}_{1}+\hat{\beta}_{3} \hat{\delta}_{1}\right) \ln F D I_{i t}+\left(1+\hat{\beta}_{4}\right) \ln G D P_{i t}+\bullet \\
& \ln V A_{\text {INDit }}=\ln P O L L_{i t}-\left(\hat{\gamma}_{3}+\hat{\gamma}_{4} \hat{\delta}_{1}\right) \ln F D I_{i t}-\hat{\gamma}_{7} \ln G D P_{i t}+\bullet
\end{aligned}
$$

Combine (D.8) and (D.9) and solve for POLLit:

$$
\ln P O L L_{i t}=\left(\hat{\beta}_{1}+\hat{\beta}_{3} \hat{\delta}_{1}+\hat{\gamma}_{3}+\hat{\gamma}_{4} \hat{\delta}_{1}\right) \ln F D I_{i t}+\left(1+\hat{\beta}_{4}+\hat{\gamma}_{7}\right) \ln G D P_{i t}+\bullet
$$

Insert (D.10) into (D.5) and solve for GDP it:

$$
\begin{gathered}
\ln G D P_{i t}=\left[\hat{\alpha}_{1}+\hat{\alpha}_{2} \hat{\delta}_{1}+\hat{\alpha}_{5}\left(\hat{\beta}_{1}+\hat{\beta}_{3} \hat{\delta}_{1}+\hat{\gamma}_{3}+\hat{\gamma}_{4} \hat{\delta}_{1}\right)\right] \ln F D I_{i t}+\hat{\alpha}_{5}\left(1+\hat{\beta}_{4}+\hat{\gamma}_{7}\right) \ln G D P_{i t}+\bullet \\
\ln G D P_{i t}=\frac{\hat{\alpha}_{1}+\hat{\alpha}_{2} \hat{\delta}_{1}+\hat{\alpha}_{5}\left(\hat{\beta}_{1}+\hat{\beta}_{3} \hat{\delta}_{1}+\hat{\gamma}_{3}+\hat{\gamma}_{4} \hat{\delta}_{1}\right)}{1-\hat{\alpha}_{5}\left(1+\hat{\beta}_{4}+\hat{\gamma}_{7}\right)} \ln F D I_{i t}+\bullet
\end{gathered}
$$

Taking the partial derivative of $G D P_{i t}$ to $F D I_{i t}$ gives the scale effect:

$$
\frac{\partial \ln G D P_{i t}}{\partial \ln F D I_{i t}}=\frac{\hat{\alpha}_{1}+\hat{\alpha}_{2} \hat{\delta}_{1}+\hat{\alpha}_{5}\left(\hat{\beta}_{1}+\hat{\beta}_{3} \hat{\delta}_{1}+\hat{\gamma}_{3}+\hat{\gamma}_{4} \hat{\delta}_{1}\right)}{1-\hat{\alpha}_{5}\left(1+\hat{\beta}_{4}+\hat{\gamma}_{7}\right)}
$$


Second, the composition effect is determined by inserting (D.12) into (D.6):

$$
\ln C O M P_{i t}=\left[\hat{\beta}_{1}+\hat{\beta}_{3} \hat{\delta}_{1}+\hat{\beta}_{4} \frac{\hat{\alpha}_{1}+\hat{\alpha}_{2} \hat{\delta}_{1}+\hat{\alpha}_{5}\left(\hat{\beta}_{1}+\hat{\beta}_{3} \hat{\delta}_{1}+\hat{\gamma}_{3}+\hat{\gamma}_{4} \hat{\delta}_{1}\right)}{1-\hat{\alpha}_{5}\left(1+\hat{\beta}_{4}+\hat{\gamma}_{7}\right)}\right] \ln F D I_{i t}+\bullet
$$

Taking the partial derivative of $C O M P_{i t}$ to $F D I_{i t}$ gives the composition effect:

$$
\frac{\partial \ln C O M P_{i t}}{\partial \ln F D I_{i t}}=\hat{\beta}_{1}+\hat{\beta}_{3} \hat{\delta}_{1}+\hat{\beta}_{4} \frac{\hat{\alpha}_{1}+\hat{\alpha}_{2} \hat{\delta}_{1}+\hat{\alpha}_{5}\left(\hat{\beta}_{1}+\hat{\beta}_{3} \hat{\delta}_{1}+\hat{\gamma}_{3}+\hat{\gamma}_{4} \hat{\delta}_{1}\right)}{1-\hat{\alpha}_{5}\left(1+\hat{\beta}_{4}+\hat{\gamma}_{7}\right)}
$$

Third, the technique effect is calculated by inserting (D.12) into (D.7):

$$
\ln T E C H_{i t}=\left[\hat{\gamma}_{3}+\hat{\gamma}_{4} \hat{\delta}_{1}+\hat{\gamma}_{7} \frac{\hat{\alpha}_{1}+\hat{\alpha}_{2} \hat{\delta}_{1}+\hat{\alpha}_{5}\left(\hat{\beta}_{1}+\hat{\beta}_{3} \hat{\delta}_{1}+\hat{\gamma}_{3}+\hat{\gamma}_{4} \hat{\delta}_{1}\right)}{1-\hat{\alpha}_{5}\left(1+\hat{\beta}_{4}+\hat{\gamma}_{7}\right)}\right] \ln F D I_{i t}+\bullet
$$

Taking the partial derivative of $T E C H_{i t}$ to $F D I_{i t}$ gives the technique effect:

$$
\frac{\partial \ln T E C H_{i t}}{\partial \ln F D I_{i t}}=\hat{\gamma}_{3}+\hat{\gamma}_{4} \hat{\delta}_{1}+\hat{\gamma}_{7} \frac{\hat{\alpha}_{1}+\hat{\alpha}_{2} \hat{\delta}_{1}+\hat{\alpha}_{5}\left(\hat{\beta}_{1}+\hat{\beta}_{3} \hat{\delta}_{1}+\hat{\gamma}_{3}+\hat{\gamma}_{4} \hat{\delta}_{1}\right)}{1-\hat{\alpha}_{5}\left(1+\hat{\beta}_{4}+\hat{\gamma}_{7}\right)}
$$

Last, the total effect can be determined by adding up the scale, composition, and technique effect. Hence, (D.12), (D.14), and (D.16) are inserted into the identity-1:

$$
\ln P O L L_{i t}=\left[\hat{\beta}_{1}+\hat{\gamma}_{3}+\hat{\delta}_{1}\left(\hat{\beta}_{3}+\hat{\gamma}_{4}\right)+\left(1+\hat{\beta}_{4}+\hat{\gamma}_{7}\right) \frac{\hat{\alpha}_{1}+\hat{\alpha}_{2} \hat{\delta}_{1}+\hat{\alpha}_{5}\left(\hat{\beta}_{1}+\hat{\beta}_{3} \hat{\delta}_{1}+\hat{\gamma}_{3}+\hat{\gamma}_{4} \hat{\delta}_{1}\right)}{1-\hat{\alpha}_{5}\left(1+\hat{\beta}_{4}+\hat{\gamma}_{7}\right)}\right] \ln F D I_{i t}+\bullet
$$

Taking the partial derivative of $P O L L_{i t}$ to $F D I_{i t}$ gives the total effect:

$$
\frac{\partial \ln P O L L_{i t}}{\partial \ln F D I_{i t}}=\hat{\beta}_{1}+\hat{\gamma}_{3}+\hat{\delta}_{1}\left(\hat{\beta}_{3}+\hat{\gamma}_{4}\right)+\left(1+\hat{\beta}_{4}+\hat{\gamma}_{7}\right) \frac{\hat{\alpha}_{1}+\hat{\alpha}_{2} \hat{\delta}_{1}+\hat{\alpha}_{5}\left(\hat{\beta}_{1}+\hat{\beta}_{3} \hat{\delta}_{1}+\hat{\gamma}_{3}+\hat{\gamma}_{4} \hat{\delta}_{1}\right)}{1-\hat{\alpha}_{5}\left(1+\hat{\beta}_{4}+\hat{\gamma}_{7}\right)}
$$

